\title{
Poems by Polish Female Poets and the Burning Issue of Religion
}

\author{
Dorota Walczak-Delanois
}

check for updates

Citation: Walczak-Delanois, Dorota. 2021. Poems by Polish Female Poets and the Burning Issue of Religion. Religions 12: 618. https://doi.org/ $10.3390 /$ rel12080618

Academic Editors: Dennis Ioffe and Klaus Baumann

Received: 3 June 2021

Accepted: 30 July 2021

Published: 9 August 2021

Publisher's Note: MDPI stays neutral with regard to jurisdictional claims in published maps and institutional affiliations.

Copyright: (C) 2021 by the author Licensee MDPI, Basel, Switzerland. This article is an open access article distributed under the terms and conditions of the Creative Commons Attribution (CC BY) license (https:// creativecommons.org/licenses/by/ $4.0 /)$.
Faculté de Lettres, Traduction et Communication, Département de Langues et Lettres, Université Libre de Bruxelles, 1050 Bruxelles, Belgium; Dorota.Walczak@ulb.be

Abstract: The aim of this paper is to show the presence of religion and the particular evolution of lyrical matrixes connected to religion in the Polish poems of female poets. There is a particular presence of women in the roots of the Polish literary and lyrical traditions. For centuries, the image of a woman with a pen in her hand was one of the most important imponderabilia. Until the 19th century, Polish female poets continued to be rare. Where female poets do appear in the historical record, they are linked to institutions such as monasteries, where female intellectuals were able to find relative liberty and a refuge. Many of the poetic forms they used in the 16th, late 17th, and 18th centuries were typically male in origin and followed established models. In the 19th century, the specific image of the mother as a link to the religious portrait of the Madonna and the Mother of God (the first Polish poem presents Bogurodzica, the Virgin Mary, the Mother of Jesus) reinforces women's new presence. From Adam Mickiewicz's poem Do matki Polki (To Polish Mother), the term "Polish mother" becomes a separate literary, epistemological, and sociological category. Throughout the 20th century (with some exceptions), the impact of Romanticism and its poetical and religious models remained alive, even if they underwent some modifications. The period of communism, as during the Period of Partitions and the Second World War, privileged established models of lyric, where the image of women reproduced Romantic schema in poetics from the 19th-century canons, which are linked to religion. Religious poetry is the domain of few female author-poets who look for inner freedom and religious engagement (Anna Kamieńska) or for whom religion becomes a form of therapy in a bodily illness (Joanna Pollakówna). This, however, does not constitute an otherness or specificity of the "feminine" in relation to male models. Poets not interested in reproducing the established roles reach for the second type of lyrical expression: replacing the "mother" with the "lover" and "the priestess of love" (the Sappho model) present in the poetry of Maria Pawlikowska-Jasnorzewska. In the 20th century, the "religion" of love in women's work distances them from the problems of the poetry engaged in social and religious disputes and constitutes a return to pagan rituals (Hymn idolatrous of Halina Poświatowska) or to the carnality of the body, not necessarily overcoming previous aesthetic ideals (Anna Świrszczyńska). It is only since the 21st century that the lyrical forms of Polish female poets have significantly changed. They are linked to the new place of the Catholic Church in Poland and the new roles of Polish women in society. Four particular models are analysed in this study, which are shown through examples of the poetry of Genowefa Jakubowska-Fijałkowska, Justyna Bargielska, Anna Augustyniak, and Malina Prześluga with the Witches' Choir.

Keywords: religion; Polish mother; Sappho; love poem; religious; Polish female poetry; 21st-century female poetry; lyric matrixes; Polish Catholic Church; feminine models of poetry; engaged poetry; body; Polish society

\section{A Word of Introduction}

As part of the Slavic tradition, Polish poetry represents much more than just a lyric form and is more than an ensemble of literary production in verse. It illuminates specific strata of society and otherwise hidden phenomena. Poetry is an artform that is sensitive to and records moods and invisible tensions contained within the human experience. 
Furthermore, poetry anticipates the future events of society and can be described as a kind of social prognostic. For example, in the period of Polish Romanticism, poets often played the role of those "who know better", as spiritual guides of the nation, savants, or visionaries. At other times, poets' aims have been projecting a voice of warning as a "guardian", an oppositionist, or a voice of common or individual conscience.

Today, in the era of the predominant medium of the internet, enabling instantaneous conveyance of texts and images in public and private forums, poetry and poets continue to be visibly involved in the life of society, and their work continues to be significant. In this paper, I am especially interested in the contribution of female poets: Is there evidence of interest in poetical discourse on religion ${ }^{1}$ ? What sorts of matrixes are present in current poems by Polish women? What is happening with their lyric form?

I explore these complex questions and express points of view from a literary-historical perspective across several epochs to explain the most interesting for me-the current situation. A close reading method was applied, especially in the last part of this paper concerning 21st-century poetry, but I also relate some other points of methodological approaches (for example, feminist approaches) when necessary. To understand the present, we must look to the past, which is why two different aspects, the style and time of writing, are considered in this paper. They are articulated in a complementary dialogue in which poems by female poets are the most interesting to me, more so than the history of religion, cultural cohabitation in ancient Poland, or important querelles on democracy after 2015. The historical approach examining the timeline of one poet can be built upon by examining the religious aspects of their poem. Both are characterised by one of the most apparent motifs: the iconic model of "Madonna". I examine the poems of female Polish poets who are interested in religion according to their beliefs or their contestations concerning religion. Further, I examine the most popular poetic forms, as well as the origin of the models and their stereotypicality. Finally, I partly examine the impact of the mutual influence between female poets and society. In such a large-scale study, attentively examining the poems is a kind of invitation to further and deeper reflection, a stimulus, and the first step before a future book publication. This transverse study of female Polish poets and the issue of religion will be the first of its kind written, in particular, for non-Polish readers. Prior works of different researchers have presented particular religious topics linked to one poet (Bogalecki 2020), to a singular period (Milewska-Waźbińska 2018), questions of atheism (Bielak 2020), or even non-evident metaphysics (Grądziel-Wójcik 2017).

The first historical part of this paper helps one to understand the subsequent contemporary analysis. The authors and works from the Middle Ages to the present day are only a select-but I hope also representative-choice of texts. Some are well known; others remain virtually unknown. Several difficulties arose in presenting this analysis. For example, the topic touches upon numerous other problematic and rich themes such as women's corporeality and spirituality; their place in Polish society; and their relationships with other women and with men, with education, with politics, and the Catholic Church in Poland, which has fluctuated over the centuries (Weintraub 1971) as it is the only one of the different faiths in ancient Poland that is predominant nowadays. When necessary, the fragments of the historical context appear as a background. As this panorama of works necessitated making choices regarding their inclusion, these choices, unfortunately, led to the omission of many interesting examples.

\section{The Particular Presence of Women in the Roots of Literary Tradition}

Critical theories of different forms of feminism but also works on history of literature assert that despite the changing position of women in society, during recent centuries, some expressions of beliefs, published in the different forms of literature, still held that a woman is often perceived as uncapable of activities beyond "running a house and raising children" (Clark 1998; Jay 2005; Radzik 2020). The iconic image of a woman with a pen in her hand was one of the most important imponderabilia in prior eras. However, there was a kind of ambivalence: women were presented as a "devil's habitat" but also a saintly 
figure. In Works and Days by Hesiod (Hesiod VIII BC 2021, pp. 80, 94, 374-75, 405-6, 700-5); in Greek mythology (Graves 1955); in the works of Pythagoras, who places woman on the side of Chaos (Perictyone 430 BC 2021); and in Aristotle's Politics (Aristotle 1984), who sought to prove the natural inferiority of an ordinary woman, her image is seldom presented positively.

As stated by Kirster Stendahl (Stendahl 1974) and Joanna Partyka, in the Book of Genesis, the Book of Proverbs, and the Ecclesiastes, women also appear as Satan's tool, the cause of pain and illness (Partyka 2004). In the Old Testament, out of more than 200 women, only a few are deemed as deserving praise: Sarah, Esther, Judith, Rachel, Rebecca, and Ruth. The appearance of Mary, mother of Jesus, in the New Testament did not create a meaningful change in the ordinary image of women. Mary stays as the unsurpassed ideal and the example to be followed as a woman humbly accepting her lot and motherhood. In the First Epistle of Paul to the Corinthians (Saint Paul, ch. 14 vs. 34-35), it is said that a woman should not speak in the Church and participate by herself because it is a shame for her community, and if she wants to learn, she should ask her husband. This tradition continued into the Middle Ages, but balance can be seen to emerge in the 12th and 13th centuries with the development of the gesta and in troubadours' lyrics. Here, women are portrayed as beautiful and intelligent, respectful but also inaccessible ladies.

In Poland, the new status of women was built alongside the emerging identity of the new state in the context of a medieval European Christian ${ }^{2}$ community, with examples such as Princess Świętosława-Sygryda (born c.a. 960-972-dead after 1016) and Queen Jadwiga-Edwidge (1372-1399), in parallel with new monastic education and the founding of the first schools and renovating Academy of Cracow (1364).

\section{From the Ancient Cultural Models to the Beginning of Polish Literature}

Many literary and historical sources confirm that the name of the first Polish female poet is Gertrude (Gertruda) (1025?-1108), the daughter of the Polish King Mesco II and the German princess Rycheza. Gertrude is well educated, probably in one of the German abbeys. Gertrude becomes the wife of the oldest son of Jaroslav the Wise (Isaslas) and leads an eventful life. She holds a position of positive notoriety in Polish and Slavic history. Historians of literature associate Gertrude with the prayer book (called Modlitewnik Gertrudy (Prayerbook of Gertrude)). She authored prayers in hundreds of volumes, as testified by her characteristic use of the literary language of the epoch and the volume: Latin. The expression of ego Gertrude accompanies the stories of the adventures of her family in the prayer book created in the period from early 1075 to late 1086. Specialists of this libelli precum write that Gertrude was also able to break with conventional forms to express the authentic individual emotions:

Beyond the Latin prayers arranged in sublime prose, there is an inner image of a woman torn apart by spiritual contradictions that give her personality the stigma of tragedy. Gertrude felt lonely, alienated from her surroundings and surrounded by enemies "visible" and "invisible". Living in a constant sense of threat, in fear of unfriendly people and of Satan, who "subjects many evils" and "captivates into slavery"-she was looking for support in religion. Her existence was suspended between the unreal, desired good and the almost tactile, almost tangible, surrounding misconduct ${ }^{3}$.

(Michałowska 2000, p. 97)

Teresa Michałowska suggested that even if Gertrude and her spiritual depiction were formed by medieval Christian models, Gertrude produces the image of an individual entangled in dramatic events and tormented by violent passions like a person divided between a religious desire for spiritual perfection and love for her son, lust for power, and hatred for her enemies (Michałowska 2000, p. 98). The first literary text composed in the Polish language, the poem Bogurodzica, appears at the turn of the 13th or 14th century (the written version is from 15th century) and became immediately popular. The title means 
"the one who gave birth to God". This great masterpiece of Polish literature from the Piast epoch and "gold autumn" of medieval Poland reveals an exceptional artistry:

Its stanzas' form indicates that it arose as a trope on the acclamation Kyrie eleison. What is probably most important, however, is the assertation that the work is wholly original. No Latin source has been uncovered, a fact that is even more noteworthy since the hymn demonstrates an almost perfect structure, a cohesive construction evincing the author's exceptional sense of beauty, manifest in its perfect symmetry and veritably mathematical precision. The work's symmetrical structure, almost faultless rhymes, and parallelisms underscored by rhyme draw our attention to its perfection of form, the perfection of this appear addressed to Mary and via her intercession to Christ, the Son and God. A detailed analysis of this prayer, wherein an entreaty is first made of Mother of God, while the second stanza speaks of the intercession of John the Baptist, allows us to discern the schema of the iconographic theme of deesis (Greek for "entreaty" or "prayer"), cultivated in Byzantine culture and assimilated by the culture of Roman Europe in the 11th-13th centuries. In deesis, as in our prayer, the central figure is Christ the Majesty, with Mary standing on the right and St. John the Baptist on the left.

(Karpiński 2004, pp. 17-18)

We do not know the name of the anonymous author of this anthem in honour of St. Mary, but we know that the author was a well-educated and talented poet. This image of Mary, from the earliest days of the Roman Church, continues to influence and form the ideal model of the woman.

During the period of the Middle Ages and from numerous countries, works appear by acclaimed female authors involving topics of religious culture. These authors include Christine de Pizan (1364-1430), Hrotsvitha de Gandersheim (935-1002), and Hildegard von Bingen (1098-1179). The writings of women all over Europe, such as Régine Pernoud (Pernoud 1998), show the considerable influence of history and culture. Gertrude, Queen Edwidge (1372-1399), Edwidge of Silesia (1174-1243), and Saint Kinga-Cunegonde (1234-1292) prepare the foundation for future generations of women. Detailed knowledge of their lives remains limited, however. The Renaissance period in Poland produced new models of poetry and new silhouettes of women who expressed themselves in the context of their function or position toward men. For example, the young Ursula, the four-year-old daughter of Jan Kochanowski (1530-1584), was called the Polish "Ronsard". She appears as an emblem of possible feminine creativity. Having died before reaching adulthood, she is the heroine of the elegies written by her famous father, Treny (Lamentations) (Kochanowski 1986). As a talented author, she is compared in the sixth elegy to the Greek poet Sappho. Julian Krzyżanowski wrote on the phenomenon of Ursula Kochanowska and the poem about her, one of the lamentations, is linked to the development of lyric form:

[The poet] made a clear distinction between two kinds of thirteen-syllable verse, when besides the more common kind $(7+6)$ :

Thou hast made this house for me / / a place of emptiness Ursula, my dearest child / / reft by thy absentness
Wielkieś mi uczyniła / / pustki w domu moim, Moja droga Orszulo, // tym zniknieniem swoim.

He also included in his Laments the rare form $(8+5)$ :

Joyous little songster of mine! / / my Slavic Sapho The heiress to whom not only / / my estate will go ... (Krzyżanowski 1978, p.102)
Ucieszna moja śpiewaczko! // Safo słowieńska, Na którą nie tylko moja / / cząstka ziemieńska ...

This important poetic image, that of Sappho, forms and transmits to the future a second strong model (apart from the medieval Madonna). Portraits of women in forms of Renaissance poetry can also be found, especially in the form of carmen or frasca, which are so cherished in Renaissance literature and beloved as much as the form of elegies. This period also produced an interesting new Polish anonymous text (not obviously present in academic literature courses) and a kind of anti-model of the female personage. This model is exemplified by Barbara Giżanka (1550-1589), the last mistress of the Polish King 
Sigismund August. Giżanka was kidnapped for him from a convent because of her physical similarity to his beloved and still mourned late wife (also named Barbara). The poem $O$ [Barbarze Giżance] (About Barbara Giżanka) presents Giżanka as a strong woman, who, introduced by the lyrical subject, talks about her colourful life, about her obliged carnal and material compromises, about unequal social hierarchy, and about the consequences of her status (she was from the middle class). This independent and lovable woman, through whose bed "both: priests and lords has passed" (Anonymous 1984, p. 244), defends herself against too-hasty judgement with energy and engagement.

The unfolding of the Renaissance and Baroque eras also produced some rare but clearly identified female poets, although a minority in comparison to men and official authors. Ursula Phillips offers precise descriptions of five women writers in the period of the 16th and 17th centuries (Borkowska et al. 2001). These authors, such as Magdalena Mortęska (1554-1631) and Marianna Marchocka (1603-1652), wrote primarily in prose, in letters, and lived under Carmelite and Benedictine rules. In the 17th century, we find the first mystic lyrics with strong characteristics of love poems:

Dusza strapiona od różnych ciężkości

Wszystka omdlewa od wielkiej teskności,

Bo się jej ukrył gdzieś Oblubieniec,

Włożywszy na nię poślubny wieniec.

Zadawszy ranę od strzały miłości,

Ukrył się prędko, a onę we mdłości

Zostawił, srodze boleścią ściśnioną,

Od wszystkich zmysłów prawie oddalona.

Myśli nieboga, co ma dalej czynić,

Kogo by miała o zranienie winić?

Nie trzeba długo z myśla tej zabawy;

Zranił mie, zranił, Oblubieniec krwawy,

Ale co cięższe, że odszedł zraniwszy,

A mnie zbolałą w żalu zostawiwszy.

(Anonymous 1998)

\author{
The soul afflicted by various burdens \\ All faint from great longing, \\ For her Bridegroom is hiding somewhere, \\ Having placed upon her the wedding wreath. \\ Having inflicted a wound from the arrow of love, \\ He hid himself quickly, and left her in weakness \\ He left her in very severe pain, \\ Out from all her senses, out of her mind. \\ The poor thing thinks what to do next, \\ Whom should she blame for her injury? \\ It does not take long to play with this thought; \\ I am wounded, I am wounded, by the bloody Bridegroom, \\ But more grievously, he went away after, \\ And left me in pain and left me in grief.
}

As we follow the manuscript canticles from women in Polish monasteries in the 17th century, sisters living in various spiritual and religious centres exchange not only letters, but also volumes of poetry and thoughts. In the example above, one can see the amalgam of a religious image of Christ and the beloved human as a "spouse" such as in the erotic, courtyard poetry of the Baroque concetto (Hanusiewicz 1998). Notably, some of these women created their own style. In Lviv, in the Polish and Lithuanian Commonwealth, the entire "writers' school" of Magdalena Mortęska appeared with the new generations of female authors. The Carmelite manuscript, which seems to be close in style to the writings of St. Teresa of Avila, records more frivolous lyrics from a convent during recreational periods:

Pódźmyż siostry zaraz po kolędzie

zali na nas pan Jezus łaskaw będzie:

Każ nam rekreować, każ nam rekreować Panno Ksieni nasza.

Którego nam Panna czysta porodziła

I powiwszy w jasełeczkach położyła:

Każ nam rekreować, każ nam rekreować Panno Ksieni nasza.

Pódźmyś tedy miłe siostry po kolędzie,

$\mathrm{Z}$ nami też wesoła Panna Ksieni będzie:

Każ nam rekreować, każ nam rekreować Panno Ksieni nasza.

$(\ldots)$
Let's go sisters after carol with visit

Let's see if Jesus will be gracious to us:

Let us have a leisure, let us have a leisure, our Lady

[Priestess.

Whom the pure Virgin gave birth

And bore him in a nativity scene:

Let us have a leisure, let us have a leisure, our Lady

[Priestess.

Let us go, then, dear sisters, to visit you,

The Lady Prelate will be with us:

Let us have a leisure, let us have a leisure, our Lady

[Priestess.

(...) 
Nasza Panna Ksieni (z) siestrzyczkami,

Każe nam wina pełnić kubeczkami:

Każ nam rekreować, każ nam rekreować Panno Ksieni nasza.

$(\ldots)$

Jużże teraz zaisadajmy wszystkie stoły,

Będziemy mieć wesele $\mathrm{z}$ apostoły:

Każ nam rekreować, każ nam rekreować Panno Ksieni nasza.

Amen

(Anonymous 2004)
Our Lady Priestess (with) the sisters,

She makes us fill in wine with cups:

Let us have a leisure, let us have a leisure, our Lady

[Priestess.

$(\ldots)$

Let us sit at all the tables now,

We'll have a great joy with apostles:

Let us have a leisure, let us have a leisure, our Lady

[Priestess.

Amen

By the 17th century, one of the rare figures of feminine poetry appears, presented in the official history of literature-Elżbieta Drużbacka (c.a. 1695-1765). Her most known poem, Opisanie czterech części roku (Description of Four Parts of Year), begins:

Bogdajżeś przepadł w piekło $\mathrm{z}$ ateista,

Ty, który mówisz, że Bóg nie jest Panem,

Ni Stwórca rzeczy! A któż oczywistą

Machinę świata oblał oceanem,

Kto słońce, miesiąc, planety w swym biegu

Komenderował, kto gwiazdy w szeregu?

(Drużbacka 1903, p. 46)

\begin{abstract}
Goddess, you are lost in hell with the atheist,
You who say that God is not the Lord,

Nor the Creator of things! And who the obvious machinery of the world has surrounded by ocean, Who sun, month, planets in their course

Commanded, who put the stars in the row?
\end{abstract}

With the fever of counter-reformation typical of the Baroque period and already in a classic form of verses, Drużbacka manifested her worldview in a period of transformation. In the beginning of 17 th century, Poland was still multi-confessional, with free choice of religion guaranteed by the Compact of Warsaw signed in 1573. This was an exceptional situation in comparison to the rest of Europe (Hernas and Hanusiewicz 1995). Thus, even when the Counter Reformation appeared, it occurred in quite a passive way-without religion wars. In this historical context, another Polish particularity appears: the Polish Enlightenment, initiated by the men of the Catholic Church: Ignacy Krasicki (1735-1801), Hugo Kołłataj (1750-1812) and Stanisław Staszic (1755-1826).

In the 18th century, Franciszka Urszula Radziwiłłowa (1705-1753), the first female author of threnodies after Jan Kochanowski (16th century), wrote an elegy bearing similarity to Kochanowski's Treny after the death of her son. In this literary and social context, her poetic atelier is significant (Judkowiak 1992):

Radziwiłł's poem was not a spontaneous creation-prepared, thought out, subjected to the rules of the genre (or genres), it captured the mother's despair. Everything suggests that no Polish woman before her had ever mourned her child in this way. The Threnody is a genre steeped in antique tradition and philosophical content-for centuries available only to men. In the 16th and 17th centuries, and even at the beginning of the 18th, as can be seen from the example of Franciszka Radziwiłł, women mourning the death of their children took on male roles. This could only be done by those of them, who had acquired "masculine" (read: classical) education. It wasn't until the 17th century in Poland, and a century earlier in France, that women would write in a "feminine" way. The lack of classical erudition would no longer stand in the way of their "literary play".

(Partyka 2004, p. 210)

"Male" erudition, which allows a woman to be a writer, was emerging, but was, at the same time, a barrier for her own creativity and her own "femininity". This obvious conflict stops when what is considered "male" or "female" in society defies rigorous definition. The real changes became visible in the 18th century with the model of the "femme savant", first inspired by developments in the Enlightenment. Even in Poland-though this period of reforms and freethinking was rather short and was a bridge between the long Baroque and still significant Romantic periods-the "women's Enlightenment" and their new role as authors allowed them to appear to be officially at the same level (Jamrożek and Żołądż 1998). Still, they 
were not as numerous in comparison to male authors and certainly less visible. The scientific discourse on literary work of women from the 18th century is more apparent. Wacław Borowy, in his memorable study about Polish poetry in the 18th century, fully described three of them: the already-mentioned Elżbieta Drużbacka, Konstancja Benisławska (1747-1806), and Antonina Niemiryczowa (1702-1780). In this trio, Drużbacka is perhaps the most known and accomplished poet whose poetry touches upon both metaphysical and religious reflections (Borowy 1978, pp. 32-34).

Until the 19th century, Polish female poets continued to be rare. Where female poets appear in the historical record, they are linked to institutions such as monasteries, where female intellectuals were able to find relative liberty and a refuge. Many of the poetic forms they used in the 16th, late 17th, and 18th centuries were typically male in origin and followed established models. In the whole period of Old Polish literature, there were few female poets writing about religion, and we know little about them. Furthermore, in the 19 th century, the specific image of the mother as a link to the religious portrait of Madonna and the mother of God appeared again as a strong and powerful motif.

\section{Matrixes of 19th-Century Romanticism}

The portrayal of the mother as an iconic and literary fact throughout previous centuries was endowed by the 19th century with an additional denotation. From Adam Mickiewicz's (1798-1855) poem Do matki Polki (To Polish Mother), the term "Polish mother" becomes a separate literary, epistemological, and sociological category (Mickiewicz 1993, pp. 320-21). The real success of the poem, beyond its artistic and technical excellence, is based on the historical and political context. Maria Janion, one of the most important Polish scholars and specialists on the history of literature, the history of feminism, and literary critics, writes:

Mickiewicz was the author of both Śmierć putkownika [Colonel's Death] and the poem Do matki Polki [To Polish Mother]. In these poems, he extolled female bravery, which had a powerful influence on the formation of women's selfawareness in Poland. He also created the legend of the self-sacrificing Polish woman, a legend to which Polish women so often conformed themselves later in their life. As a result of Romantic dictates, Polish women became accustomed to carrying the burdens of family and public life in the shade and in silence, as long as the sacrifice was fulfilled.

(Janion 2006, p. 99)

In 1772, 1793 and finally in 1795, the territory of Poland was divided and incorporated into Russia, Austria and Prussia for 123 years. Russian and German language, legal code, education system, and even the religious choices in some historical moments were imposed on Poles for more than a century (Beauvois 2004). After 1830, after the November Uprising, the persecutions and repression of Poles led to new religious interpretations and comparisons, but not only by Poles (Malinowski and Styczyński 2008). These emerging ideas considered Poland to be in the position of a suffering Christ, whereby his mother becomes one of the stylistic figures of the image of the Polish woman and mothers who suffer from the persecution of their children. As Julian Krzyżanowski writes:

So, whereas for some Messianism was a program of an armed fight for liberation, for others it turned into a quietist attitude, waiting for a miracle that would, without any effort on the part of man, bring freedom to the world, for slavery was in opposition to the notion of divine justice. Still others, taking the principles of Messianism as a basis, maintained that God had saved Poland from taking an active part in rotten political life which was based on the rule of force of the imperialist states, in order to resurrect her at the moment when these states had become just a part of the shameful past. As these ideas were occupied with biblical symbols in such formulations as: Poland, the Messiah of the nations; Poland-the Christ; Poland-Mary Magdalene, etc., the whole of this nebulous mixture gave and still gives the impression of religious and political speculation, 
to such an extent that it overshadows the original, simple and noble greatness of the principles, as greatness that was understood by those who, living outside Poland at the time, had read Mickiewicz's brochure, Books of the Polish Nation, which was a kind of national bible.

(Krzyżanowski 1978, p. 225)

The Biblical, Messianic comparisons emerge in different variants and they provide a new, but still limited, legacy to the woman considered the most noble: the Polish mother as Christ's mother. In a Romantic landscape, one can also find a woman-lover or a woman-knight (and rarely, Mary Magdalene); they are less present and less powerful in their influence or their strength. Of course, the forms of lament, elegy, and rhapsody are still preferred in poetry and are connected to the religious connotations. The fact that only men-Adam Mickiewicz, Juliusz Słowacki (1809-1949), and Cyprian Kamil Norwid (1821-1883) (or even Zygmunt Krasiński (1812-1859)) — could obtain the title of national bard or national guide ("wieszcz") is significant. As was the norm for this period, mothers would educate poets and suffer for them but stand at a distance (as well as their daughters) from the places of the first poetic tribune. However, due to the context of suffering and struggling for independence, women regained a bitter form of equality in accordance with the Tsarist decree of 1863, which introduced equal military courts for offenders of both sexes. Pointing to the similarities between the 19th and 20th centuries, Maria Janion reminds us that:

The imprisonment of most of the male leaders (similar to what happened in the 19th century, which was further depopulated by the military emigration of men after the November Uprising) meant that women took over the leadership and united the shattered movement. Those men who were not arrested reportedly did not know how to direct underground activity. The women did their heroic and anonymous work in secret, which was never discovered because it would have conflicted with the established belief that women should not lead.

(Janion 2006, p. 99)

In the second half of the 19th century and the beginning of the 20th century, various female poets, such as Bronisława Ostrowska (1881-1928), Maria Komornicka (1876-1949), Maryla Wolska (1873-1930), Kazimiera Zawistowska (1870-1902), and Maria Konopnicka (1842-1910), write in accordance with the spirit and soul of the era, but they do not significantly influence either the social matrixes or the poetical schema of lyric in relation to the issue of religion. However, their presence in the literary scene is important because it allows the possibility of new developments in the 20th century.

The opinion regarding the impossibility of leadership by women throughout the 20th century is extant within the Polish Catholic Church, but is also often found in the opinions that Polish women have of themselves (Duch-Dyngosz et al. 2014).

\section{Post-Romantic and Other Uses in the 20th Century}

Throughout the 20th century (with some exceptions), the impact of Romanticism and its poetical and religious models remain alive, even if they undergo some modifications. The period of communism (1945-1989), as during the Period of Partitions and the Second World War, privileged the models of lyric where the images of women reproduce Romantic schema in poetics from the 19th-century canons. Even in a lyric of Kazimiera Iłakowiczówna (1892-1983), an independent woman fascinated by the beginning of feminism and at the same time fervently Catholic, one cannot find substantial changes in the models in her poems. As a secretary of Józef Piłsudski, but also due to her numerous talents and unpredictable character, she was famous in Warsaw during the 1920s and 1930s. In her poems from this period (Iłłakowiczówna 1926, 1927, 1928, 1930) and in her religious volume from the 1960s (Iłłakowiczówna 1967), no significant changes can be observed when comparing these works to the Baroque and Romantic periods, even if her style is recognisable, as is her particular traditional form and religious reflection (Głowiński 1960; Ratajczak 1998; Marzec 2018). 
Such Romantic models continue to function in the lyric of most 20th-century female poets. Thus, over time, the "new" lyric monologue can be seen from poets such as Krzysztof Kamil Baczyński (1921-1944) Elegia o chłopcu polskim (Elegy about a Polish Boy) (Baczyński 1994). Here, the poet incorporates the role of a mother losing, in the sacrifice of a war battle, her son; this "iron" model of the mother is still alive throughout the 20th century, even if, as stated in the poem written by Agnieszka Osiecka (1936-1997) Polska Madonna (Polish Madonna), the nature of "motherhood" changes over time:

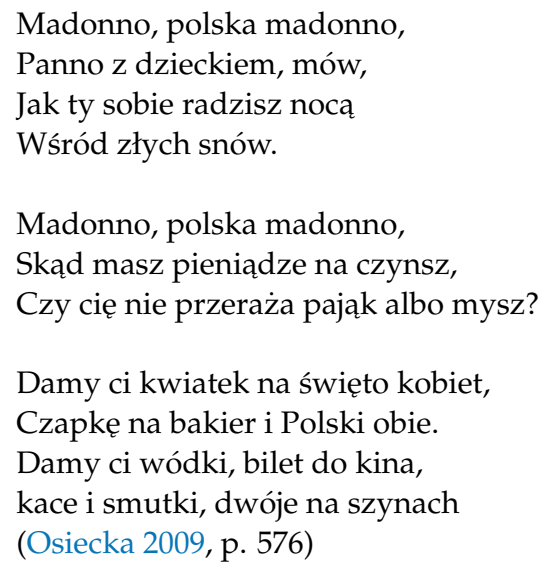

\begin{abstract}
Madonna, Polish Madonna, Maiden with child, speak up, How do you manage at night Among bad dreams.
\end{abstract}

Madonna, Polish Madonna, Where do you get the money for rent, Aren't you terrified of a spider or a mouse?

We'll give you a little flower for Women's Day, A beanie on the back and both of Polands. We'll give you vodka, a ticket to the cinema, flunks and sorrows, double digits on the rails.

Osiecka contemporises the religious vision of the Madonna from the past, but still places it in the context of Polishness and as a kind of social and patriotic martyrology. Here, you are the woman who "has to" finally assume the ancestral role of the mother but also many other roles. In feminine poetry, there is no breaking with the repetitiveness of the model because in times of war and after the period of communism, it also serves as one of the identifiers of Polish society.

It was in the male lyrical sphere, which was traditionally more visible, where there were 20th-century metaphysical poetry and poetry regularly depicting themes of the sacred or being in dialogue with religion. For many readers of poetry, it is rather evident to mention well-known and popular names such as Tadeusz Miciński (1873-1918), Bolesław Leśmian (1877-1937), Jerzy Liebert (1904-1931), Roman Brandstaetter (1906-1987), Karol Wojtyła (1920-2005), and the immensely popular, Father Jan Twardowski (1915-2006), with his everyday topics. No such list for women is evident.

In the 20th century, the return of the other, shy model can be observed. This returns to the model of the Muse, the Poet herself, and to Sappho (mentioned previously by Kochanowski in the elegy for Ursula) after Poland regained independence in 1918, after which the poet could be finally free of martyrologic topics. The "motherhood" and "Madonnahood" seem to be of less interest here. We find in the 1920s and 1930s an interesting example in the poems written by Maria Pawlikowska-Jasnorzewska (1891-1945), a popular poet, who published a dozen volumes up to 1939. She breaks social rules and covenants with her three marriages and divorces; with the disputes with her uncles and ecclesiastics; with her sensual poetry, such as in her poems from cycle Róże dla Safony (Roses for Sappho), recalling the need for love rather than different religion; and with the still-existing ambiguous Sapphic themes:

Gdy świat Safonę odrzucał,

Gdy jej dorobek palono,

Buchnęły dymy różane

Ociężała, chociaż szaloną

Chmura płynęły przez czas.
When the world to Sappho closed its ears, When the fire consumed the work of years, Rose-laden smoke rolled up to the skies; Gath'ring, heavy but delirious A cloud remaining through centuries.

I breathed it in on a windy day, Poetry is with us, here to stay ...

Wciagnęłam ja z wiatrem w płuca,

Poezja nie poszła w las ...

kowska-Jasnorzewska 1978, p. 576) 
Her poetic voice mostly appears in the form of frasca and miniatures freed from the eroticism of the parabolic and religious contexts so common in the Baroque period. She chose to avoid religious topics and replaced sacrifice with free love. Even if in an ironic half-humour, she criticises one of her uncles-a bishop. He is violet in his clothes but also violet in his dry and sad heart, always with the old women in the church, reading old books and unable to love and to laugh, and passing by the most important aspects of life, as described in the middle stanza of the poem O fiotkowym biskupie (About a Violet Bishop) (Pawlikowska-Jasnorzewska 1997, p. 67).

In the 20th century, other women follow Jasnorzewska in the replacing of matrixes, e.g., Halina Poświatowska (1935-1967), who makes a kingdom of the feelings of love in her poems. With no interest for the traditional Catholic religion, and no interest for meanderings of reflections and political quarrels, she, like an antique Sappho, is the priestess of her own religion-love. Stanisław Grochowiak (1934-1976) writes about her (Grochowiak 1959), recalling her Hymn batwochwalczy (The Idolatrous Hymn) (Poświatowska 1958) and her heart disease:

Her love of life had something intrinsically religious about it, yet it was a forbidden religion, condemned in advance to ingratitude and lack of grace, an idolatrous religion. Here was a woman whose every living movement of the heart threatened death, worshipping unrestrained, sensual, carnal love.

(Grochowiak 1967)

God, named, appears rarely in material, sensual love that is oriented firstly to another beloved human. When God is directly mentioned, it is in the context of suffering and questioning of existence:

Boże mój zmiłuj się nade mną czemu stworzyłeś mnie na niepodobieństwo twardych kamieni

pełna jestem twoich tajemnic wode zamieniam $\mathrm{w}$ wino pragnienia wino-zamieniam w płomień krwi

Boże mojego bólu atłasowym oddechem wymość puste gniazdo mojego serca

Lekko-żeby nie pognieść skrzydeł tchnij we mnie ptaka o głosie srebrnym z tkliwości

(Poświatowska 2000, p. 342)
My God, have mercy on me why hast thou made me inimitable of hard stones

I am full of your mysteries I change water into wine of thirst wine I change into the flame of blood

God of my pain with a satin breath sweep away the empty nest of my heart

Lightly—so as not to crumple the wings breathe the bird into me with a silver voice of tenderness

However, it was written in a study about Poświatowska's lyric that: "The last book which aroused her interest and which she read before her death was the Bible. And we will never know whether this had anything to do to the transformation of her sensualist worldview, which rejected religious consolation ... " (Dumowska 1986). It is precisely the new expression of suffering that helps the poet refine the dialogue and interests manifested in the themes of love, self-affirmation, and interruption of the pietà model.

A new generation of female poets appears in the 1970s: the real internal aspects, inside a poem and in a poetic transformation, undergo a metamorphosis. An interesting example of this is Anna Świrszczyńska (1909-1984). Her poems, especially those from the 1970s, contain a considerable amount of rebellion and a new distance from the canons of consciousness and an awareness of choice. One of her best-known volumes, Jestem baba, 1972 (I am the Old Woman), shows the frailty of imposed convention, explaining the vast range of perceptions - a kind of self-affirmation; it is pride in being a "baba" (in familiar speaking: a nasty broad). Zbigniew Bieńkowski writes about this volume that: 
And suddenly there is such a confession, blatant, brutal, desperately brave. No woman has ever spoken out so emphatically, since poetry is poetry. I must make a great effort not to quote. Because here any quotation would only be an example of brutality, unbeauty, finally: unpoetry at last.

(Bieńkowski 1993, pp. 201-3)

Świrszczyńska poses a problem for critics who are unable to cope with the new, brutal, "meaty" writing of a poet previously known from artistic canons. Similarly, in the next volume, Budowatam barykade (I Built the Barricade, 1974), the author refers to the thirty years after the war as the time of the Warsaw Uprising and demonstrates the need to create a new language of stories about difficult wartime experiences. Świrszczyńska points to the agency of the woman's " $\mathrm{I}$ ", visible even in the title. A new feeling of experience, showing a separate, own perspective, which means more than a passive bearing of the consequences of wars, deaths of men, casemates and prisons, or even loneliness, needs to be expressed. Świrszczyńska's creative juxtaposition is worthy of attention because we also see from its example various readings of the poetry changing over time. Despite the poet regarding herself as a declared atheist and a person firmly rooted in the Earth, Czesław Miłosz (who, with a young team of researchers, translated her poetry into English) presents herself as a metaphysical poet. However, Magdalena Heydel follows the readings of the critics of her poetry (Miłosz, Bieńkowski, Balbus) and argues against this view by re-reading Świrszczyńska. Heydel does not agree with Miłosz and shows the poetry of Świrczyńska becoming écriture féminine avant la lettre (Heydel 2013, pp. 225-35); Heydel also looked for parallels between the poet's thrifty language and the concept of creativity presented in a theory by Hélène Cixous (Cixous 1975). However, the problems of re-reading and re-interpreting concern many other poems, not only these by Świrszczyńska, and belong to a new practice of the 21st century, when the question of the woman's "I" grows with the impact of religion in societal forms.

In the 1970s and 1980s, the work of two more poets, whose names are worth quoting in the context of our considerations, flourished: Joanna Pollakówna (1939-2002) and Anna Kamieńska (1920-1986). The former often describes the dysfunctional and ageing body in a new form of lament linked to the image of Job. For the first time since the Romantic and blasphemous monologues of Mickiewicz and Słowacki, from the times of their Great Improvisations ${ }^{4}$, and from Iłłakowiczówna's poetry, she transformed the monologue of a male poet into a monologue of a female poet. As in the famous monologues of the Polish Romantic hero Kordian at Mont Blanc or Konrad in a convent of Basilicans, the " $\mathrm{I}$ ", the poet requests explanations from God, as in her Kanikuta (Canicule):

Czemu tak długo trwa ta próba bólu? Już i zwątpiłam i wstałam w ufności; zawrzałam buntem i w pokorze ścichłam. Doświadczasz nadal. Puenta wciąż nie rychła i niepojęte sensów zawiłości.

W niebieskim żarze kanikuły wiecznej miłość się Twoja nigdy w chłód nie skłania. Nie ma schronienia i nie ma ucieczki. Brak odpowiedzi bo-nie ma pytania. (Pollakówna 2012a, p. 423)
Why does this trial of pain take so long? I have already doubted and stood up in trust; I have boiled by rebellion And in humility I have quieted down. You are testing me still. The puenta is not quick And incomprehensible complexities of sens.

In the blue heat of the eternal canicule Your love never turns cold. There is no refuge and no escape. There is no answer For-there is no question. 
After a long period of seeking, we obtain a real, metaphysical question, which is not merely interest in attending to and confirming the ideal religious models (such as the mother and the Madonna) or oppositional or by-passing attitudes (Sappho, lover), but real, true dialogue: the will to dialogue with God:

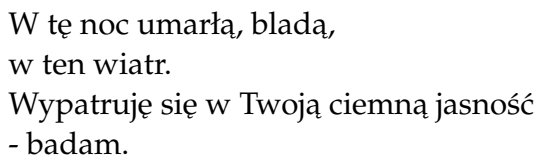

Tym bolesnym i chromym duktem, jakie mi prawdy czuło-okrutne zawierzasz?

Czy wyrok mi wymierzasz, czy przesłane tkliwe i unerwione jak płatki irysów, gdzie zarys map nieczytelnych czyjejś marszruty plany zarosłe $\mathrm{z}$ kwiatowym puchem.

Słów Twoich rytmy głuche, słów Twoich kształty zatarte - czarne szumy. (Pollakówna 2012b)
In this dead, pale night, in this wind.

I look out into your dark brightness - I explore.

With this painful and lame track, what tender and cruel truths do You entrust to me?

Do You pass judgment on me, whether sent tender and innervated like the petals of an iris, where the outline of illegible maps of someone's route plans overgrown with floral down.

Your words of deafening rhythms, Your words of blurred shapes - black hums.

This lyrical dialogue occurs in the intimate sphere far away from institutions, politics, and social engagement. Anna Kamieńska presents another attitude. Throughout the whole of the 20th century, Kamienska is the only clear, decisive, widely read, and poetically recognisable example of religious engagement, whose works are accompanied by metaphysical questioning. An important breakthrough in her rich oeuvre occurred with the death of her beloved husband Jan Śpiewak (1908-1967) and then her meeting and friendship with a well-known personality and poet, Father Jan Twardowski. Kamieńska, a seeker, underwent a conversion and became a Dominican Tertiary involved in pastoral work. She participated in Christian Culture Weeks, signed protest letters against the communist authorities (Letter 59), and appealed in the defence of striking workers (Appeal 64). She also led and taught during Christian retreats. Her poems are engaged in a dialogue with the presence of God in his undoubted existence, as in Przebudzenie (Awakening):

Dzień dobry Panie Boże

więc mamy zaczynać od nowa

było już tak ciemno

a Ty obmyłeś wszystko

deszczem światła.

Dzień dobry Panie Boże

dałeś ptakom nowy głos

pszczoła przyszła do nowego miodu

liść rozsunał pokrywy

wszędzie lśnią kropelki łaski.

Nie znaj samego siebie ale prędko otwieraj oczy i uszy

krzew postrzępiony płonie

obłok zmartwychwstaje.

(Kamieńska 1981a, p. 57)
Good morning my Lord, God

so we have to start again

anyway it was already so dark

and You have washed everything

with a rain of light.

Good morning, my Lord, God

You gave a new voice to the birds the bee came to new honey

The leaf has spread its lids droplets of grace shine everywhere.

Do not know yourself

but quickly open your eyes and ears

the frayed bush is burning

the cloud rises from the death.

The dark of the Polish 1980s was a period with no liberty of expression, no calm life in the society of the regime, and with threat of imprisonment and daily renunciations. Once again, the poetic romantic figure of the suffering mother returns, as in Stabat Mater: 
Pod tym krzyżem, gdzie rozdarta umierała w nocy Polska w lodach Wisły w śniegu grudnia stała Matka Częstochowska.

W tłumie matek popychana, osiwiała, ledwie żywa

pod tą brama, pod tym krzyżem stała Matka Boleściwa.

Okutana szata z lodu, poczerniała i milczaca

solidarnie z ludem swoim stała Matka Bolejąca

Zatrwożona i bezsenna jak dziś każda z polskich matek przytuliła nas do serca, gorzko mocząc łzą opłatek.

Matko nasza, Matko Boża poorana, cała w troskach większą wiarę i nadzieję daj nam Pani Częstochowska.

(Kamieńska 1981b, p. 61)

Under that cross, where Poland, torned, was dying at night

in the ice of the Vistula River, in the snow of December, Our Lady of Czestochowa was

[standing.

In the crowd of mothers-pushed, gray-haired, barely alive

Under that gate, under that cross, the Mother of Sorrows was standing.

Covered with a robe of ice, blackened and silent

the Sorrowful Mother was standing in solidarity with her folk.

Scared and sleepless like every Polish mother today

hugged us to her heart, bitterly wetting the hots-wafer with tears.

Our Mother, Mother of God, scarred and troubled

Give us greater faith and hope, Lady of Czestochowa.

One should not forget that in the 1980s—-the most significant for Kamieńska's creationsthere was a strong presence of the Polish Catholic Church, which organised cultural and laic events in the parishes in the period of censure when many scenes, theatres, and cultural organisations were forbidden and closed. The Church also helped in caring for workers and strikers. Censoring religious sentiments helped ${ }^{5}$ strengthen the popularity of such religious poetry.

Furthermore, in the Polish poetic paysage, some poems abrogate the essence of the old secular-religious debate. The female authors consider declarations of faith as a private matter even if they are involved in its discussion. Wisława Szymborska (1923-2012), Nobel Prize winner in 1996, is an example of such a voice. She shunned the model of poetry, situating herself outside the issue of religion in poetry, flirting with the ideology of socialism (but, of course, not outside human values common to religious universal codes of values as: compassion, generosity and kindness towards the other (Tomasik 2009)); in interviews, she declared herself as an atheist. In her poem Głos w sprawie pornografii (Voice on Pornography), with perspicacity, irony, and humour, she takes the floor, pointing to the innocence of "pink buttocks" and nudity in the face of the influences of thoughts, sometimes the most perverse (Szymborska 1996, pp. 130-31). In the social reality of the new, liberal Poland of the late 1980s and in the 1990s after the fall of the Berlin Wall, sex shops sprang up like mushrooms after the rain. 
Yet, the new 21st century will bring interesting poetic phenomena by Polish female poets. The romantic topoi, e.g., of the ever-popular Polish mother, have returned, but in a renewed form, challenging the social and the literary stereotypes established over the centuries.

This time it is about the revindication of a different " $\mathrm{I}$ ". One can notice an abandonment of "I"'s function in the poetry of irreligiosity and a clear return to the dialogue with the previous forms of religion and its contents functioning in Polish poetry.

For the first time in Poland, women and female poets have become present in this thematic climate in the mainstream literature, linked to their new roles in society and new debates concerning the entrenched role of the institution of the Catholic Church in Poland.

\section{HIC and NUNC-The Burning Issue of Religion in the 21st Century}

The female poets of the 21st century break with the hitherto existing ways of talking about religion in verse. Their presence is much more visible and linked to the social and cultural changes occurring at the turn of the 20th and 21st centuries in Poland, Europe, and the world. Models previously rare or non-existent appear as a worthy way of living: a businesswoman, a "singielka" (single, not in a couple), an LGBT+ activist, a feminist, a vegan, an ecologist, a militant woman, etc. Changes have also appeared in the Catholic Church and other Christian communities in Poland. Girls can now serve during mass near the altar, as the boys do. The first LGBT parades have appeared, as well as massive demonstrations connected to the tightening of the anti-abortion law (loudly broadcast and visible in the media, called the "black marches"). There have been responses to these changes in Poland, such as smaller but still apparent marches on the knees and men praying with rosaries, adepts of the traditional roles of women, and the interdiction of abortion. In 1990, religious education (only Catholic) was transferred from the parish to primary and secondary schools, sparking discussion on ministerial salaries of the priests already paid by Church in the years of runaway inflation.

In the second decade of 21st century, as a special and contesting answer to the new programme of governmental ideas after the 2015 elections, the first book on sexual education for young girls, \#sexedpl. Rozmowy Anji Rubik o dojrzewaniu, miłości i seksie (\#sexedpl. Anja Rubik talks about puberty, love and sex), written by the famous Anja Rubik, a top model, appeared and was immediately sold out (Rubik 2018). This is one of the rare European books on the subject of anticonception and sexuality - a subject still staunchly avoided during religion lessons in Polish schools. The older, pioneer Polish book by Michalina Wisłocka: Sztuka Kochana (Art of Loving) has been re-edited in large print (Wisłocka 2016), and the biography of Wisłocka has been transferred to the screen (Sadowska 2016). Interesting works on the Church and Catholic women were published in Emancypantki. O kobietach, które zbudowaty kościót (Emancipantes. About Women who built the Church) (Radzik 2018) and in Kościót kobiet (The Church of Women) (Radzik 2020) by Zuzanna Radzik (born in 1983). As a theologian, journalist, and the president of the Forum for Dialogue (on Polish-Jewish dialogue), she constitutes an example of a possible and important input as a new, spiritual, and also feminist voice in the written history of women in the Church from the beginning of the Early Christian communities.

How do female poets - the vigilant recorders of reality - react to these huge changes? We observe a departure from linguistic shamefulness, a somewhat energetic, sometimes frenetic, new flow (Maliszewski 2020). In official poetical discourse, for the first time, strong, vulgar, and anatomic words appear, accompanied by theses, which belong to the "sacrum" sphere. For the first time, strongly expressed and distinguishable anticanons have appeared. I indicate some of them here. They are written by contemporary female poets.

a. Genowefa Jakubowska-Fijałkowska (born in 1946) is one of the most expressive and interesting poets today, and a testimony that maturity and a late debut can be an asset. Her poetry, from the first poems printed on the pages of "Odra" and the volume Dożywocie (Life imprisonment) (Jakubowska-Fijałkowska 1994) until her final Rośliny mię- 
sożerne (Carnivorous plants) (Jakubowska-Fijałkowska 2020a), is characterised by a sharply expressed observation of the world, perceived through the subject's painful experiences: the death of loved ones, experiences of illness, and the ageing of the body. The sharpness of her pen-razor is mixed here with humour; the analysed sense of one's own femininity is juxtaposed with the masculinity encountered in the necessary complementation, but also in incomprehension. Although parallels can be drawn with the world of Świrszczyńska's late poems (the disintegration of corporality, the discomforts of age, the contrast between enthusiasm and the stereotypical expectations of women of a certain age), in JakubowskaFijałkowska's poems, these contents are expressed with the force of fire and with ordinary communicative language.

Her works are a kind of older woman's manifesto, in the form of a dialogue with religion, which is mixed as a variable constant into the world of everyday human laic affairs. There is something Franciscan and tender in this, after all, very violent rebellion in defence of the weak (animals and plants) and those who cannot cope with the Polish version of capitalism: derailed, lost men and women who are tired of life and devoid of dreams. I quote what the critic and the reviewer, Wojciech Szot, wrote about this work, awarded the NIKE nomination in 2017:

I call it, for my own use, 'postmenstrual poetry', where a mature, simply old poetess reveals to the person reading her world, which she experiences with a slight piss. It is beautiful that next to fatigue, a slight resignation, in JakubowskaFijałkowska's work there is a discord with old age, when "I dye my fucking grey hair/henna ruby flows down the whole tub with paint", which reminds the lyrical subject of menstruation and how "communist lignin rubbed my thighs every month". He writes:

at seventy I'm fucking with it all again

with hair dye like I did with blood then

( ... ) If Jakubowska-Fijałkowska lived in the States, her poems would be recited by celebrities at political rallies like they now quote Maya Angelou. And so, we are a country of poets, where the so-called "Enzensberger constant" is a fact.

(Szot 2017)

Although the poems of this female poet from Mikołów evoke common experiences in a communicative and seemingly ordinary, banal expression, we observe a shift in the canon. Here, in the poem: ten diabet ciagle maci (this devil is still messing about), Fijałkowska's alter ego, a lyrical subject, is not the child-bearing Madonna, but the tempted and bleeding Jesus:

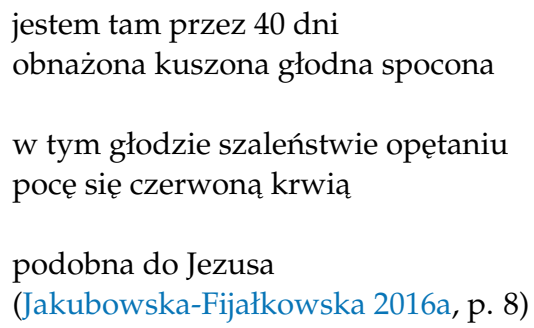

like Jesus

A similar lyrical situation, according to the terminology of Edward Balcerzan (Balcerzan 1970, pp. 333-86), is repeated in a poem, Wielkanoc 2018 (Easter 2018), where we read: "poce się krwia przed ukrzyżowaniem/w noc wielkanocna w koszuli nocnej jęczę" (I sweat blood before the crucifixion/on Easter night in my nightgown I moan) (Jakubowska-Fijałkowska 2020b, p. 16).

It is not just a symbolic substitution, an exemplification of corporality, and strong carnal exhibitionism; in this poetry, the sensation—also brutal and ugly —of one's own body is the basis for asking important questions about the possibility of good religion, about the humanity of God, about the legitimacy of dogmas, and about one's own shape of faith, as in the poem Bóg powrócit do miasta (God has returned to the city): 


\author{
i mężczyzna \\ szukam go (boga i mężczyzny) \\ w Istambule na lotnisku \\ palę $\mathrm{w}$ miejscu wydzielonym \\ przy barze wypijam brandy z lodem \\ za szybami samoloty kołuja \\ (ptaki daleko gdzie indziej) \\ i znowu palę $\mathrm{w}$ miejscu wydzielonym \\ i wypijam druga brandy (przy barze) \\ muezin nawołuje do modlitwy \\ jest czwarta nad ranem \\ minarety wbijają się we mnie wieżą wysoką \\ jak penis boga
}

gdy na lotnisku w toalecie spuszczam dżinsy rajstopy majtki i sikam

(Jakubowska-Fijałkowska 2016b, p. 10). and a man

looking for him (god and man)

in Istanbul at the airport

I smoke in a designated area

at the bar I drink brandy on the rocks

behind the glass planes are taxiing

(birds far away somewhere else)

and I smoke again in a designated area and I drink another brandy (at the bar)

the muezzin calls for prayer

it is four o'clock in the morning

the minarets are hitting me with their high

towers like a god's penis

when at the airport in the toilet I flush

jeans tights panties and pee

God (this time written with a capital letter) can be found again in the juxtaposition of the pair, visible also in the title, Mężczyzna i Bóg (Man and God):

Bóg jest moim mężczyzną w lipcu

$\mathrm{w}$ innych miesiącach

odległością skalista pustynią doliną śmierci cudnym krajem astronomii

szamanką w stringach

mam swoje obserwatorium Boga i mężczyzny w średnicy Drogi Mlecznej

w paznokciu wrośniętym w duży palec stopy $\mathrm{w}$ linii papilarnej do visy USA

(Jakubowska-Fijałkowska 2016c, p. 42).
God is my man in July

in other months

a distance a rocky desert a valley of death the wondrous land of astronomy

a shamaness in T-string

I have my observatory of God and man in the diameter of the Milky Way

in the nail embedded in the big toe in the fingerprint to the USA visa

The authors' poetry features many paraphernalia common to the age-old, established repository of religious and fatherland identifiers in the Polish space: a silver chain with a medallion of the Virgin Mary; a watch received at a celebration of communion, as in Ucho van Gogha (Van Gogh's ear) (Jakubowska-Fijałkowska 2016d, p.13); a holy picture with the pierced heart of Jesus, as in Osiedlowy spleen (Bloc quartier's Spleen) (JakubowskaFijałkowska 2016e, p. 19). Here, along the same lines, appear the presence of a James Bond-like handsome priest-steward in a white alba who brings the Body of the Lord in W sobote koło dziewiatej rano (Saturday around Nine O'clock in the Morning) (JakubowskaFijałkowska 2016f, p. 22) and the biblical stories of Eve and Judith woven into the everyday as in Ruletka z toba, (Roulette with You) (Jakubowska-Fijałkowska 2016g, p. 45).

When we carefully read her poems, we notice the presence of different fragments of rituals and in-church ceremonies, which include common agendas of religious and laic festivities. At different levels, the poetical " $\mathrm{I}$ " is involved in the community by questioning the sense of gestures and established models. "I" uses them as the signposts and timesensitive signs, as in Święcona woda (Holy Water) (Jakubowska-Fijałkowska 2020c, p. 40), 
Trzech Króli szóstego stycznia 2018 (Epiphany on 6 January 2018) (Jakubowska-Fijałkowska 2020d, p. 28). Boże Narodzenie 1986 (wspomnienie) (Christmas 1986 (souvenir)) (JakubowskaFijałkowska 2020e, p. 30), and Wielkanoc 2017 (Easter 2017), (Jakubowska-Fijałkowska 2020f, p. 35).

In a simple way, Jakubowska-Fijałkowska shows the incoherence between dogmas, ecclesiastical laws, and common practices, as in Jezus żonaty (Jesus married) (JakubowskaFijałkowska 2020g, p. 37) or in Niedziela (Sunday):

kobiety w garsonkach

z małymi torebkami Diora z lumpeksu

modlą się na mszy

w nich (torebkach) komunijne skarbczyki różańce pamiątki chusteczki perfumy pomadki złamane [rzęsy

w każdą niedzielę ksiądz błogosławi wszystko w małej torebce prezerwatywę też

to taki grzech seks przez gumke (Jakubowska-Fijałkowska 2016h, p. 44) women in suits with little Dior handbags from the second-hand shop

are praying at mass service

in them (bags) communion treasuries rosaries souvenirs handkerchiefs perfumes lipsticks broken

[eyelashes

every Sunday the priest blesses everything in a small bag a condom too

it is such a sin to have sex through a condom

Finally, Genowefa Jakubowska-Fijałkowska points to ancient memories and stereotypes to comment on the recent black marches and protests against politics. Here, the experiences common across generations and the heavy and rich heritage of this Polish mother occur again in the poem Rodza się dziewczynki (Girls are being born) (JakubowskaFijałkowska 2016i, p. 50). In many of her poems, we observe a militant tune and real anger. The result is the very reaction in the poem Wszystko zawsze na matce wisi (Everything always hangs on the mother) to the right-wing government:

Jarek płacze nad rozlana jego spermą

zakazuje in vitro

twoje ciało nie należy do ciebie

PIS się wpierdala w twoja macice jajniki

w pochwę wargi sromowe

w twoja pierś karmiąca w zapaleniu boląca

gdy odciagasz mleko

sutki bolą krwawią przeżyj to prezesie

sama sobie strzelę $\mathrm{w}$ krocze

wtedy się odwalisz ode mnie

(Jakubowska-Fijałkowska 2020h, p. 23)
Jarek weeps over spilling his sperm

bans in vitro

your body doesn't belong to you

PIS fucks with your uterus, your ovaries

into vagina into labia

into your breast that feeds in inflammation that hurts when you pump milk

nipples hurt, they bleed, live it up, president

I'll shoot myself in the crotch

then you'll fuck away from me

With a strong lyrical subject, she discusses the body without taboos in all possible dimensions, and, above all, in its physiology and dysfunction, sexuality and pleasure in the ageing process. This voice of concern is, however, one of the rare poetic propositions that build a universe, a specific world where religion appears on different levels and " $\mathrm{I}$ " tries to cope with her entanglement, with its "now" evaluated, a distanced and ironic outlook, and the input of poems as well as with the emotional charge of histories, revealed in a language, symbols, designations, and names. Both coexist in a startling way.

b. The poetry of Justyna Bargielska (born in 1977) represents the second type of the poetical relation of a female poet with religion. Having received important awards-Rainer Maria Rilke Poetry Competition (2001), the Jacek Bierezin Special Award (2002), and Gdynia Literary Award (2010, 2011) — for her first volume, Dating sessions (Bargielska 2003), she 
explores the world from her own, subjective feminine perspective; at the same time, she breaks the conventional ways of writing. This portrays the freshness in her compositions, the smashing of existing hierarchies, her linguistic and conceptual collages with a kind of crazy selfness, and a simultaneous evident compositional and intellectual rigor. In a dialogue with religion-clearly visible in the last volumes in funny, sometimes falsely childish ways, and sometimes spoiled and ugly speaking-she examines the most important taboos concerning a woman's body to finally question the essential limits of life and death. In one poem, Ona liczy na seks (She Counts on Sex), the presence of Christ and his resurrection are parallel to a love-rebirth of " $\mathrm{I}$ ", waiting for her lover. In this poem, in the very centre, we find a declaration of a belief, hidden in a word game-PIS (a main right-wing governmental party) off-piss off:

Kościół obstaje przy grzebaniu ciał, tłumacząc, że sam Chrystus chciał być pogrzebany. Pewnie, przecież miałem zmartwychwstać, a nie odrodzić się z popiołów jak feniks, mówi Chrystus, ale to nie znaczy, że inni nie moga się odradzać z popiołów jak feniks, mówi Chrystus i jest naprawdę pissed off na ten głupi Kościół. Jak feniks. Za cztery godziny cię zobacze, cokolwiek sie stanie, zobaczę cię za trzy godziny. (Bargielska 2012a, p. 18)
The Church persists that corpses be buried explaining that Christ himself wanted to be buried. Sure, I was going to be resurrected, and not be reborn from ashes like a phoenix, says Christ, but it doesn't mean that others can't be reborn from ashes like a phoenix, says Christ and He's really pissed off at this stupid Church. Like a phoenix. In four hours I'll see you, whatever happens, I'll see you in three hours. (Bargielska 2012b)

Here, belief is much more important than the ultra-Catholic parties and bigger than the institution of the Catholic Church. The separated words "says Christ" and "He's really like a phoenix" are the most meaningful; but the reader has to join them to make sense and throw the "obstructing" words out: "pissed off at the stupid Church". In many of Bargielska's other poems, we see the presence of a childish idiolect. As Marta Koronkiewicz writes:

The woman-child becomes at the same time enfant terrible, an expositor of games and conventions, of limitations and entanglements, whose method is to "overlook" certain boundaries. The figure of a child turns out to be a figure of shamelessness, although at the same time the term "shamelessness" is tempting. Bargielska's heroines are shameless, slutty maids from good homes. From the beginning of her work, the author has been exploring this specific register, such as reproof, the whole idiolect connected with the process of bringing up girls.

(Koronkiewicz 2014)

Bargielska, as discussed in the critical paper, is problematic for critics because, inter alia, she is able to answer in an interview: "Why shouldn't I believe in God? I believe." (Nawarecki 2013, pp. 403-16), and in her poetry: "Why shouldn't I have a romance? I have." (Bargielska 2012c, p. 24). She is able, in the same disingenuous way, to build parallels between women, daughters, and mothers, as well as between herself and Jesus:

Tak szczerze, to myślę, że nie wiesz, czym jest tęsknota.

Czy twoja córka powiedziała ci kiedyś

pięćdziesiąt trzy razy pod rząd, że pies ci je kapelusz?

Niech je, powiedziałam. Nie wiem, czy choć raz. Twoje maile

to nie maile, to pieszczoty, dzisiaj pójdę spać z toba,

mówi mi mail. Nie, mailu, dzisiaj pójdziesz spać z żona,

a ja pójdę spać $z$ mężem. Niemniej nie dalej niż jutro

planuje pozbyć się ze świata wszystkich naczyń, 
do picia, do sikania, przechowywania prochów bliskich, zbierania krwi naszego Zbawiciela, i będę ostatnim naczyniem na świecie. I, umówmy się, ja i krew Zbawiciela, tylko my dwie wiemy, czym jest tęsknota.

Has your daughter ever told you

fifty three times in a row that the dog's eating your hat?

Let it, I said. I don't know if it was even once. Your emails aren't emails, they're caresses. Tonight I'll go to sleep with you, the email says to me. No, email, tonight you'll go to sleep with your wife, and I'll go to sleep with my husband. Nevertheless no later than tomorrow I plan to rid the world of all vessels, those for drinking, peeing in, storing loved ones' ashes, for collecting our Saviour's blood, and I will be the last vessel in the world. And, let's be clear, our Saviour's blood and I, only we two know what yearning is.

(Bargielska 2012e)

In Jak to widzi sowa (How the Owl Sees This), the poet's begging prepares the lyric "I" for maternity. She positions herself in a modern life, with the wise, considerate, and conscious (owl); but knowledge does not protect her. She will choose to believe, even if it cannot free her of hesitations and dilemmas, as shown in a fragment of the poem:

Sześć tygodni płaczu, że takie szczęście jest możliwe sześćdziesiąt kolejnych tygodni, że za nie dziękuję sześćset, że przepraszam, że w nie wierzyłam, sześć tysięcy, czy można je już zabrać ode mnie. Więc wierze, ale proszę, nie przychodźcie do mnie, tym bardziej nie przysyłajcie jedni drugich nawzajem. (Bargielska 2014a, p. 25)

\begin{abstract}
Six weeks of crying that such happiness is possible sixty consecutive weeks that I thank for it six hundred that I am sorry I did not believe in them, six thousand, can one take them from me away. So I believe, but please do not come to me, all the more reason not to send each other.
\end{abstract}

The palpable isolation seems to be doubled in the world of this poetry and concerns the life of a human being as well as a life according to the Church's code. The strong illustration of this solitude can be seen in Cenne jest Jagniatko (Baby Lamb is Precious):

Czy przygody Chrystusa nie były wymyślone?

I nagle idę łąka, a słyszę tunel. Ksiądz mówi: ciało Chrystusa,

a ja słyszę: proszę tẹ kartkę zabrać do domu

i ćwiczyć, ćwiczyć, ćwiczyć głoskę za głoska. To ćwiczę,

głoskę za głoska. Kto tu nie był, ten nie wie:

ani to limbo, ani plaża. Kto tu nie był, ten nie zrozumie.

Ale postaram się przybliżyć wam to miejsce,

to miejsce ma wiele ścian, a ty w nim siedzisz i myślisz:

Po co zabijać noworodki, przecież kupiłabym,

choćby do dalszej sprzedaży albo na narzady.

Were the adventures of Christ not invented? 
And suddenly I am walking through a meadow, and I hear a tunnel. The priest says: the

[body of Christ,

and I hear: please take this piece of paper home

and practise, practise, practise vowel by vowel. So, I practise,

vowel by vowel. Whoever has not been here does not know:

this is neither a limbo nor a beach. Whoever has not been here will not understand.

But I will try to bring this place closer to you,

this place has many walls, and you sit in it and think:

Why kill newborn babies, I would buy them,

if only to next sell or for organs.

Since Rafał Wojaczek (1945-1971), an engaged and contested poet who proposed an innovating and individual tone, there has been no such voice in poetry. Since then, no poems have come to such a discussion with the Church. The position of a woman's voice, here, is different and new, based on strong antagonisms in a lyrical self-expression: very intimate and a kind of exhibitionism, with precision of announcement and a hidden sensum. I quote, one more time, her poem $Z$ głębi kontinuum (From the deep continuum), from the volume Bach for my baby:

Kotku, nie chcę Tego ciagnać. Kotku, może nie brnijmy w To dalej.

Kotku, o ile mi wiadomo, Nasze Szczęście jest niemożliwe ze względów fizycznych i mam na myśli tę naprawdę Dużą Fizykę, tę, która mówi, że możesz być

w dwóch miejscach naraz, tylko jeśli jesteś

Bogiem lub Martwy. Będąc Martwym Bogiem,

o, wtedy to masz, możesz być Wszędzie.

A wiesz, kto miałby teraz w głowie

Martwego Boga, gdybym ja nim była?

Ale nie o tym chciałam. ( ... )

(Bargielska 2012f, p. 32)

\author{
Baby, I do not want to drag this out. Baby, \\ maybe we shouldn't go on. \\ Baby, as far as I know, Our Happiness \\ is physically impossible \\ and I mean the really Big Physics, \\ the one that says you can only be \\ in two places at once, only if you're \\ God or Dead. Being a Dead God, \\ oh, then you've got it, you can be Anywhere. \\ And you know who would have a \\ Dead God right now if I were him? \\ But that's not what I wanted to talk about it (... ).
}

The strength of Bargielska's poetry lies, as in the quoted excerpt, in her ability to deeply reflect upon the conflict between humans and God. Unlike the felt corporeality in Jakubowska-Fijałkowska's model of poetry, in Bargielska's poems, there is no possibility of self-identification with him as understood as the corporeal man, nor is he understood as a spiritual god. There can only be a body or spirit, closer or approximative rapprochement. There is no spiritual communion, and the choice is always dramatic.

c. In the poetry of Anna Augustyniak (born in 1976), we observe an interesting, new proposition and combinations of different unusual backgrounds. Here lies the questions of life and death, of redemption and religion, mixed with the problems of animal rights and the tendency of an ecological and vegetarian viewpoint. In the whole volume entitled Między nami zwierzętami (Among us animals) (Augustyniak 2020a), the poet deals with us: the barbaric, illogical human and our shaky opinions on the world of civilisation and the world of nature. The alter ego, named in the poems as Anna Q, asks eschatological questions in the logic of the Decalogue and in a reflection on physical (action-reaction, full-empty) words, as in the poem o Annie $Q$ i pytaniach (about Anna $Q$ and questions): “Czy pytanie o zasadność zabijania jednych dla drugich,/Nie jest najpilniejsza kwestia współczesnego świata? (Is the question of the legitimacy of killing some for others,/the 
most pressing issue of the modern world)" (Augustyniak 2020b, p. 42) or in the poem $o$ trawieniu (about digestion) in more brutal and persuasive way:

Spożywani też czekają na zbawienie?

W teologii nadziei może chodzić o przyszłość trawionych.

Kto liczy, ile trupich szczątków do ust włożył,

Ile z odbytu jego wyszło

I spłynęło rurami kanalizacyjnymi

Gdzieś w głębiny szamb?

Ile przetrawionych istot czeka na zbawienie?

(Augustyniak 2020c, p. 11)
Are the consumed also waiting for salvation?

The theology of hope may be about the future of

Who counts how many corpses remains he has put [into his mouth,

How many-came of his anus out And flowed down the sewer pipes Somewhere in the depths of septic tanks?

How many digested beings are waiting for salvation?

The poems of Augustyniak, in a new, empathic, but also documented, manner, investigate the established dogmas, important texts, and ways of their interpretation. The author annotates additional poems with footnotes, in which she clarifies the specific religious and ecclesiastical points of understanding for the possibly unfamiliar reader. The matter-of-fact and seemingly emotionless tone and the explanation of things apparently familiar to Christians, especially to Polish Catholics, result in the sharp and painful irony, as in the poem $o$ nieboszczyku (about a dead man):

Ponoć wypieranie zwłok ze świadomości To poważny problem społeczny. Spójrzmy więc, jak anatom Zwykł się przyglądać doczesnym szczątkom, Na najsłynniejszy w dziejach organizm, Na mięso i krew Chrystusa

Jego mięso i krew zeszły się z nim najściślej,

Bliżej nie mógłby być nawet z Bogiem Ojcem.

W widowisku na krzyżu zmagał się

$\mathrm{Z}$ namacalnością $\mathrm{w}$ męczeństwie

I przetworzył agonię w najchodliwszy towar ${ }^{(4)}$,

Lądujący teraz i na wieki na językach ludzi.

(4) Bierzcie i jedzcie, to jest ciało moje—mówi Chrystus i mówi kapłan podczas liturgii mszy św., a wtedy hostia, którą ściska w palcach przeistacza się w ciało Chrystusa i można je konsumować. (Augustyniak 2020d, p. 8)

(4) Take and eat it, this is my body, says Christ, and the priest says it during the liturgy of the Mass, and then the host, which he squeezes in his fingers, is transformed into the body of Christ and can be consumed.

The volume's weight is heavy, especially when the reader follows, poem after poem, a kind of special "list of killing"; a "list of crimes" appears that obliges us to consider our human (or animal) motivation for acts. It can be read as a sort of answer, for example, to the volume by Rafał Gowin Jem miesso (I eat meat) (Gowin 2019) or to the world's statistics of excessive consumption of food in some parts of globe and poverty in others. Yet, this is also a sharp discussion within the framework of respecting fundamental social rules (Franciscan's brotherhood of being) and individual and institutional responsibility for words and acts:

O śmierci zamienionej w pokarm

Serce przestaje bić.

Mózg może jeszcze o czymś myśli

\begin{abstract}
Suppressing carcasses from consciousness
Suppressing carcasses from consciousness
is a serious social problem.

Used to look at mortal remains,

On the most famous organism in history, The flesh and blood of Christ
\end{abstract}

His flesh and blood came together most intimately,

Closer he could not be even with God the Father.

In the spectacle on the cross He struggled With palpability in martyrdom

commodity ${ }^{(4)}$,

Landing now and for ever on the tongues of men 
Za późno.

Ciało już jest mięsem

I przemienia się $\mathrm{w}$ potrawy

W ciemne ludzkie sprawy,

Z kręgu zabijania i jedzenia,

Wnika z każdym kęsem,

W każdą tkankę,

W węzły życia,

W więzy krwi,

Krew się z krwią zaczyna mieszać,

W żywe cmentarzysko konwertuje,

Przepoczwarza w monstrum.

Pijcie, bierzcie, jedzcie.

Na talerzu sen wieczysty

Krowy, wołu, owcy, kozy.

Grzech nie dotyczy zwierząt:

Św. Tomasz ${ }^{(5)}$ to przesądził,

Dusze nierozumne,

Za to jakie smaczne mają ciała.

(5) Św. Tomasz z Akwinu przysposobił teorie Arystotelesa, odmawiając zwierzętom posiadania duszy i w katolickiej teologii do dzisiaj funkcjonuje taki model myślenia, a przecież Bóg, lepiąc z prochu ziemskiego ciała zwierząt, tak samo jak człowiekowi tchnął im w nozdrza dech życia. "Jednako tchna wszystkie, i nie ma człowiek nic więcej nad bydlę".

On death turned into food

The heart stops beating.

The brain maybe still thinking about something

Too late.

The body is already meat

And turns into food

Into dark human affairs,

From the circle of killing and eating,

It penetrates with every bite,

Into every tissue,

Into the knots of life,

Into the ties of blood,

Blood begins to mingle with blood,

It converts into a living graveyard,

It transforms into a monstrosity. 
Drink, take, eat.

On a plate of eternal sleep

A cow, an ox, a sheep, a goat.

Sin does not concern animals:

St. Thomas has determined this,

Souls without understanding,

But what tasty bodies they have.

(5) St. Thomas Aquinas adopted Aristotle's theories, denying that animals have souls, and in Catholic theology, this model of thinking continues to operate to this day; yet God, in fashioning the bodies of animals from the dust of the earth, breathed into their nostrils the breath of life just as he did into human's. "They are all the same, and man has nothing more than a beast".

In this context, the poems of Augustyniak, with referees, deductions, and data, are like a new kind of manifesto, opposite to those of the futurists, and are joyful or a kind of new poetical treaty. Here, the hidden emotions of the poetical "I" are put into the shape of "reasonable". The personage, Anna Q, is a woman, but there is no distinguished gender role in the process of the devouring. When Augustyniak writes about the "holocaust of animals" in a shocking way (Augustyniak 2020c), the guilty laid on everyone, both men and women.

My next and the final example of recent poetry is yet another form of poetic proposal. Here, emotions are primordial and become a common shout.

d. This poetry was written as protest songs, and the poems written by Malina Prześluga (born in 1983) create a total composition with a performance (music, costumes, make-up, and movement). The model of the witch replaces the model of the Madonna here. For the first time since the solidarity strikes in the 1980s, we have a strong common subject in the text; the plural lyrical "I", called Chór Czarownic-The Witches' Choir. It was formed in Poznan, in one of its current districts (previously a neighbourhood) called Chwaliszewo. There, 500 years ago, for the first time in Poland, a woman was accused of being a witch and she was burned. Starting from then, women accused of witchcraft were burned at the stake all over Poland (but not as often in comparison with the other parts of Europe). However, the first performances by Chór Kobiet (Women's Choir, later renamed as The Witches' Choir) gained huge popularity. Women dressed in satin petticoats, barefoot, and with red lipstick, singing outdoors, playing the drums:

Twoja władza, twoja wiara

Moja wina, moja kara

W twoich rękach jest mój świat

Masz mnie w garści milion lat!

Popatrz na mnie w oczy prosto Jestem twoja matka, siostra Jestem twoją córka, żoną. Stoję z głowa podniesioną. Milion nas tak teraz stoi Żadna z nas się już nie boi. Milion nas tak teraz stoi Żadna z nas się już nie boi.
You are faith and government Mine are guilt and punishment All my world is in your hands In your grasp for many years!

Look at me now, in my eyes I'm your mother, I'm your wife, I'm your daughter, I'm your child. I'm not coming here alone Millions of us standing tall Not afraid of you no more Millions of us standing tall Not afraid of you no more. 
Stoję, krzyczę, stoję, krzyczę,

Stoję, krzyczę, stoję, krzyczę,

Milion nas tak teraz stoi

Żadna z nas się już nie boi.

Potężniejsza niż myślałeś

Oddaj wszystko, co zabrałeś

Twoja wina, twoja wina

Twoja bardzo wielka wina!

Twoja wina, twoja wina,

Twoja wina, twoja wina!
Stand proud, stand shout

Stand proud, stand shout

Millions of us standing tall

Not afraid of you no more.

Stronger than I ever was

Give back what you took from us!

Through your faults, through your faults Through your faults, through your faults Through your faults, through your faults Through your faults, through your faults! (Prześluga [2016] 2017, performed by Chór Czarownic ${ }^{6}$ )

The "I", das Ewig-Weibliche (von Goethe 1982, p. 545), plays with cultural archetypes and stereotypes. For the first time in official streaming, one can hear a violent message with uses of vulgarisms. Why? The evoked primacy and the primitivism of the corporal attitude are here to underline the main problem - the desacralisation of woman-in a religious but also in a cultural meaning. It is not an accident; a similar message can be found in Kaciki ust (The Corners of the Mouth), where, in the refrain, we discover such a transformed woman talking in the singular first person, an affirmative " $\mathrm{I}$ ":

$$
\begin{aligned}
& \text { Jestem pies obronny } \\
& \text { Suka bez łańcucha } \\
& \text { Gryzę, warczę, wyję } \\
& \text { Na pieszczoty głucha. }
\end{aligned}
$$

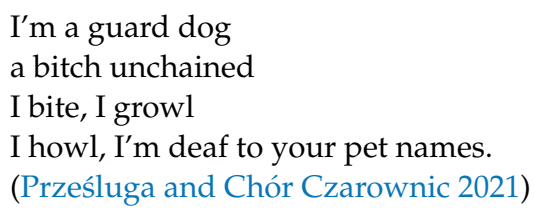

We are far from the secular and still-repeated model of the Polish mother, the Madonna, the sublime Muse, or the original and singular Sappho, and even further from the image of Mary Magdalene (rarely) appearing in Polish female poetry. Here, in the performances of the Witches' Choir, there is no place for penitence. I quote one more fragment from a poem in the repertoire of the choir, where not only a shout but also some amazing statistics can be found, as well as a reaction to the patriotico-religious "mixture" of recent years. The title, a fragment of the Catholic liturgy using the name of Poland, is significant Polska—oto stowo pańskie (Poland-this is the Word of the Lord) (Prześluga and Chór Czarownic 2012a):

Jesteśmy krajem tak bardzo katolickim

Że nawet ateiści są tu w większości katolikami

Co prawda niewierzacymi, ale praktykujacymi.

Z badań wynika, że 70\% bierze śluby kościelne $\mathrm{mmm}$

$74 \%$ chrzci swoje dzieci mmmm

$28 \%$ katolików wierzy w reinkarnację $\mathrm{mmmm}$

(...)

W kościele kobiety mogą robić rzeczy

Podobne do ich obowiązków.

Tak jak opiekują się dziećmi

Moga się opiekować chorymi.

Tak jak dbają o porzadek

Powinny sprzątać kościół.

Bo to taki zmysł trzeba mieć,

Żeby obrus był czysty

Kobieta ma naturalne predyspozycje do tego.
We are such a Catholic country

That even atheists here are mostly Catholics

Admittedly non-believers but practising.

Surveys show that $70 \%$ get married in a church $\mathrm{mmm}$

$74 \%$ baptise their children $\mathrm{mmmm}$

$28 \%$ of Catholics believe in reincarnation $\mathrm{mmmm}$

(...)

In church, women can do things

Similar to their duties.

Like they take care of children

They can take care of the sick.

Just as they take care of order

They should clean the church.

For it is such a sense to have,

To keep the tablecloth clean

A woman has a natural aptitude for this.

(Prześluga and Chór Czarownic 2012b)

This text, which is a fragment of the Magnificat performance, was presented during the Fourth Congress of Women in Poland in 2012. Through the language of messages and statistics mixed with fragments and collage statements of clergy and politicians, the 
liturgy mercilessly exposes the ongoing patterns in Polish space. Frustration is caused by the lack of new reforms and the lack of implementation of those already approved, for instance, about the possible and necessary laicisation of clothing for people in spiritual roles in Catholic clergy, as anounced by Second Vatican Council 1962-1965 in "Perfectae caritatis" document from 28 October 1965 (Pope Paul VI 1965). However, the poetics of rebellion and shouting cannot continue for long: the shock caused by the violation of taboos and the juicy novelty of expression - as the history of poetics shows-finally become banal. In response to the femininity and nudity, new Polish neoconservaitve trends were born-not in a protest song, but through business and affluent influences, as shown by the recent brand of Krzysztof Ziętarski. He is the founder and propagator of a new (and very lucrative) mode of dress for Catholic women (no trousers, only skirts and dresses) ${ }^{7}$. His "Marie Zélie" proposes polite clothes that cover most parts of the body. As he says:

What I consider to be Catholic in fashion appears in the notes of St. Marie-Azélie Martin, who, while taking care of her daughter' dress, was also mindful of the danger of falling into vanity. For although clothing should follow trends, it should be treated with the attention it deserves, in the context of our other earthly concerns. In Catholic terms, the first place belongs to God.

(Ziętarski 2020)

However, exposing the body in poetry, sometimes in a very exhibitionist way, aligns with the mechanism of taking the words off, finally using them as a form of sometimes brutal detachment and to uncover the bones-the essential part. This poetic treatment certainly links to the condition of our "useful and used body" (Agamben 2016) and the transformation we are living. One wonders then, if finally, this is not a revenge of the immaterial, stimulated by the concrete, now visible by the female poets who threw out in their creations not only their clothes but even the covering words.

\section{Conclusions}

In the considerations of poems by Polish women and the issue of religion, I have focused on Christianity, especially on the Catholic Church, as it is the most representative in Polish social and cultural space. There were no research results for Judaism, Protestantism, Orthodoxy, or Islam, for example, which were present in Poland of the Two Nations (16th-18th centuries), but are a small minority in today's Republic of Poland. Separate studies should be devoted to these issues. Additionally, it is the Catholic Church, with its impact on society, that seems, nowadays, to be the most important partner in the dialogue on religion in Polish society and literature. The poems by female poets quoted in this article are, of course, only several (deliberately) selected examples. Whereas they were relatively non-existent or small in number in earlier centuries, there are many more present from the end of the 19th century. However, in this paper, I have highlighted texts and authors that seem to me recognisable, as well as being recognised and noticed by readers and critics, but not often shown and compared together in such a study. These poems reflect historical and cultural social determinants and conditions, but also the influence, as we have seen, of important events in the heart of the country.

To draw some precise points, my conclusions from this poetic and fascinating journey are:

1. The accessible heritage of the canonical texts of Christianity, fundamental for European and world humanities as well as for Polish literary tradition, encourages neither a present nor a sympathetic view of the role of women in the sphere of religion and Church rituals. The educated strata of women, princesses and nuns, in the space of civitas christiana, which is broader than the state will, for centuries, work for change and the participation of women involved in and willing to speak out about issues of religion.

2. Poetry records social changes often invisible to the untrained eye, and sometimes anticipates them. The first text written in Polish is a poem. It is a hymn to the Virgin Mary, the anonymous poem Bogurodzica, written by a man or a woman, which conveys 
to us the image of a woman-a model of the virtues of the Madonna, the Mother of Jesus. The Romantic period perpetuates the religious parallels between the image of Mary, the Mother of Christ, and the suffering Pietà, the Polish mother, whose image was transmitted to us by Mickiewicz in a poem under such a title. This concept-image is referred to by successive generations of women and poets, who either copy the established models or rebel against it. The rebellion is based on the change in roles; the lyrical "I" in a poem is no longer Mary, but a Christ-Saviour in the 21st century, for example, in the poetry of Jakubowska-Fijałkowska. The protest may also, in another dimension of a rebellious gesture, as in the poetic songs of Malina Prześluga and the Witches' Choir, strive for the annihilation of roles fixed in society and at the same time recall the existing models.

3. Until the beginning of the 20th century, Polish female poets, wishing to appear on the literary scene of the epoch (in which they lived and shared their experiences and religious knowledge) and to become part of the poetic mainstream, used well-known (by men) matrixes and models, such as the elegy after the loss of a dear person. The image of a suffering mother, modelled on the Madonna, and the poetic form of such an elegy, are so fused together that, again, to form a description and bring it closer to the reader, 20th-century poets reached for the lyricism of the role and suffering of the Polish mother, for example, in Baczyński's poem.

4. Poets not interested in reproducing this image and the established roles reach for the second type of lyrical expression, replacing the "mother" with the lover and the priestess of love. Distant in time and poorly present, the Sappho model is newly evoked (Maria Pawlikowska-Jasnorzewska). In the 20th century, the "religion" of love in women's work distances them from the problems of the poetry engaged in social and religious disputes, constituting a return to pagan rituals (Hymn idolatrous of Halina Poświatowska) or to carnality free from maturity, not necessarily in traditional, "polite" aesthetic (Świrszczyńska).

5. It is only since the 21st century that Polish poets have been speaking out on issues of state rights connected with the aspirations of the Catholic Church in Poland. Living in a Catholic society, female poets observe the incompatibility of rituals, catechesis, civil rights, and social behaviours (Jakubowska-Fijałkowska); they cultivate new poetic forms, mixing two separate models of faith and commentary on religion with carnality and sensuality, which does not always fit with the Decalogue or the Church's messages (Bargielska).

6. Religiously solidified poetry is the domain of few single female author-poets, and it appears at times when religion and faith become a form of solace and a choice of inner freedom, harmonising with a chosen life stance, as in the poetry of Kazimiera Iłłakowiczówna or Anna Kamieńska, or when it also becomes a form of therapy in a bodily illness, e.g., in Pollakówna. This, however, does not constitute an otherness or specificity of the "feminine" in relation to male models. In the 21st century, Polish female poets are able to declare themselves in their poems as engaged feminists and Catholic believers at the same time. As shown by Zuzanna Radzik, in her works quoted above, feminist and Catholic works can be fused to be a model for Polish social space without so deep contradictory frustrations for contemporary female poets. Even if - like in the case of Witches' Choir - the opposite, strong and rebel role model towards Catholic one is today also proposed.

Cesare Ripa, in his Iconology, represents "religion" as a woman with her face covered by a thin veil, holding a book and a cross in her right hand, and in her left hand, a flame. The woman is accompanied by an elephant (being a symbol of religion), more pious than the other animals (Ripa 2013, pp. 356-57). It seems to me a beautiful illustration to contemplate within the context of our considerations. Over the centuries, in Polish poetry, which is recognised internationally by prestigious juries of all kinds of awards and translations into many languages, there has not been a single female poet who has been truly spiritual and metaphysical, engaged in a real debate with God, never mind the political context. There is 
no single Polish Emily Dickinson. So, perhaps in this old iconological image evoked here lies the answer to the question: why?

Polish female poets, over the centuries, have tried to manage with the cross and the flame. They have certainly attempted to unveil the mystery of religion as well as uncovering-discovering their own face and body in their poems, through flames and books, and experiences across the long expanse of age-from a girl to an old woman —as if they become for themselves a new religion.

Funding: This research received no external funding.

Conflicts of Interest: The author declares no conflict of interest.

\section{Notes}

1 I will base my discourse on the definition of religion and some of its components on various sources: definitions from Encyklopedia Języka Polskiego (2021), Dictionnaire des religions (Eliade and Couliano 1990) Dictionnaire des faits religieux (Levallois and Iogna-Prat 2019, pp. 1103-5), Literatura a religia. Wyzzwania epoki świeckiej (Bielak and Tischner 2020), and The Brill Dictionary of Religion (von Stuckrad 2007).

2 The year 966, the date of the beginning of Christianisation (baptism of Mesco I), is considered to be the beginning of Poland.

3 All quotes and titles are translated by the author of this paper unless otherwise indicated.

4 I mean here the most famous literary monologues in Polish Romantic poetry, which are in fact a verbal duel of the young men with God. One was pronounced by Konrad in Dziady by Adam Mickiewicz (Mickiewicz 1832, pp. 62-77), the other by Kordian, in Kordian by Juliusz Słowacki, (Słowacki 1834, pp. 70-74).

5 Censorship in post-war Poland was officially in place from 1946 to 1990-firstly, through the Główny Urząd Kontroli Prasy, Publikacji i Widowisk (Main Office of Control of Press, of Publications and Performances); and after 1981, through the changed name Główny Urząd Kontroli Prasy, Publikacji i Widowisk (Main Office of Control of Publications and Performances).

6 The translated text of the Prześluga and Witches' Choir in English is by Thimothy Williams; in the Project of Ewa Łowżył—-see references below.

7 This is not something exceptional in religious behaviours. Similar modes are found in contemporary Islam or Judaism.

\section{References}

Agamben, Giorgio. 2016. L’Usage des corps. In Idem, Homo Sacer, L'integrale 1997-2015. Translated by Marilène Raiola. Paris: Seuil.

Anonymous. 1984. O [Barbarze Giżance]. In Patrzac na rozmaite świata tego sprawy. Antologia polskiej poezji renesansowej. Edited by Jadwiga Sokołowska. Warszawa: Państwowy Instytut Wydawniczy, First written in 16th century.

Anonymous. 1998. Glińska, Anna. Przyczynek do dziejów poezji karmelitańskiej. Charakterystyka i wybrane wiersze z rękopisu o sygn. 3643 I ze zbiorów Biblioteki Jagiellońskiej. Barok. Historia-Literatura-Sztuka 10: 184-94, First written in 17th century.

Anonymous. 2004. [Zbiór kolęd i pastorałek], manuscript Archiwum Sióstr Karmelitanek Bosych w Krakowie na Wesołej, sygn. A 69, (mf.ABMK Lublin 2658), quotted after: Partyka, Joanna. In “Żona wyćwiczona": kobieta piszaca w kulturze XVI i XVII wieku. Warszawa: Instytut Badań Literackich PAN, First written in 17th century.

Aristotle. 1984. The Politics. Translated, Introduction, Notes and Glossary by Carnes Lord. Chicago: University of Chicago Press, pp. 42-80, First written in c.a. 335-323 BC.

Augustyniak, Anna. 2020a. Między nami zwierzętami. Gdańsk: Słowo/obraz terytoria.

Augustyniak, Anna. 2020b. o Annie Q i pytaniach. In Eadem, Między nami zwierzętami. Gdańsk: Słowo/obraz terytoria.

Augustyniak, Anna. 2020c. o trawieniu. In Eadem, Między nami zzierzętami. Gdańsk: Słowo/obraz terytoria.

Augustyniak, Anna. 2020d. o nieboszczyku. In Eadem, Między nami zwierzętami. Gdańsk: Słowo/obraz terytoria.

Augustyniak, Anna. 2020e. o śmierci zamienionej w pokarm. In Eadem, Między nami zwierzętami. Gdańsk: Słowo/obraz terytoria.

Baczyński, Krzysztof Kamil. 1994. Elegia o chłopcu polskim. In Idem, Utwory zebrane. v. 2. Edited by Aniela Kmita-Piorunowa and Kazimierz Wyka. Kraków: Wydawnictwo Literackie. First published in 1942.

Balcerzan, Edward. 1970. “Sytuacja liryczna”—Propozycja dla poetyki historycznej. In Studia z teorii i historii poezji, Red. Głowiński, Michał. seria II. Ossolineum: Wrocław-Warszawa-Kraków.

Bargielska, Justyna. 2003. Dating sessions. Kraków: Wydawnictwo Zielona Sowa.

Bargielska, Justyna. 2012a. Ona liczy na seks. In Eadem, Bach for my baby. Wrocław: Biuro Literackie.

Bargielska, Justyna. 2012b. She Counts on Sex (Ona liczy na seks). Translated by Katarzyna Szuster. Available online: https://www. versopolis-poetry.com/poet/53/justyna-bargielska (accessed on 21 February 2021).

Bargielska, Justyna. 2012c. Suknia barwy pogody. In Eadem, Bach for my baby. Wrocław: Biuro Literackie.

Bargielska, Justyna. 2012d. Pies ci je kapelusz. In Eadem, Bach for my baby. Wrocław: Biuro Literackie.

Bargielska, Justyna. 2012e. The Dog's Eating Your Hat (Pies ci je kapelusz). Translated by Maria Jastrzębska. Available online: https:/ / www.versopolis-poetry.com/poet/53/justyna-bargielska (accessed on 21 February 2021). 
Bargielska, Justyna. 2012f. Z głębi kontinuum. In Eadem, Bach for my baby. Wrocław: Biuro Literackie.

Bargielska, Justyna. 2014a. Jak to widzi sowa. In Eadem, Nudelman. Wrocław: Biuro Literackie.

Bargielska, Justyna. 2014b. Cenne jest Jagniątko. In Eadem, Nudelman. Wrocław: Biuro Literackie.

Beauvois, Daniel. 2004. L'effacement de la carte européenne (1795-1918) in Idem. La Pologne: Histoire, société, culture, Paris: La Martinière.

Bielak, Agnieszka. 2020. Alternatywy religii w świecie odczarowanym. Twórczość Wisławy Szymborskiej. In Literatura a religia. Wyzwania epoki świeckiej. Literatura polska po 1945 roku-Kierunki, idiomy, paradygmaty. Edited by Agnieszka Bielak and Łukasz Tischner. Kraków: Wydawnictwo Uniwersytetu Jagiellońskiego, vol. II, pp. 571-604.

Bielak, Agnieszka, and Łukasz Tischner, eds. 2020. Literatura a religia. Wyzwania epoki świeckiej. Kraków: Wydawnictwo Uniwersytetu Jagiellońskiego.

Bieńkowski, Zbigniew. 1993. Ćwierć wieku intymności. Szkice o poezji i niepoezji. Warszawa: Agawa.

Bogalecki, Piotr. 2020. “Boga zastapiłam światem”. Wiara i świeckość w poezji Krystyny Miłobędzkiej. In Literatura a religia. Wyzwania epoki świeckiej. Literatura polska po 1945 Roku—kierunki, idiomy, paradygmaty. Edited by Agnieszka Bielak and Łukasz Tischner. Kraków: Wydawnictwo Uniwersytetu Jagiellońskiego, vol. II, pp. 321-50.

Borkowska, Grażyna, Czermińska, Małgorzata, and Phillips Ursula. 2001. Pisarki polskie od średniowiecza do wspótczesności. Przewodnik. Gdańsk: Słowo/obraz terytoria.

Borowy, Wacław. 1978. O poezji polskiej w XVIII wieku. Warszawa: Państwowy Instytut Wydawniczy.

Cixous, Hélène. 1975. Rire de la Méduse et autres ironies. Paris: L'Arc.

Clark, Elisabeth A. 1998. The Lady Vanishes: Dilemmas of a Feminist. Historian after “Linguistic Turn". Church History 67: 1-31. Available online: www.jstor.org/stable/3170769 (accessed on 13 February 2021).

Drużbacka, Elżbieta. 1903. Opisanie czterech części roku. In Stanisław Konarski, Elżbieta Drużbacka, Skarbiec Poezyj Polskiej. Antologia. seria I. Edited by Antoni Lange. Warszawa: Wydawnictwo Alfreda Zonera, vol. 1. First published in 1752.

Duch-Dyngosz, Marta, Gawin Magdalena, and Radzik Zuazanna. 2014. Miejsce kobiety, "Znak" nr 714. Available online: http:/ /www. miesiecznik.znak.com.pl/7142014z-magdalena-gawin-i-zuzanna-radzik-rozmawia-marta-duch-dyngoszmiejsce-kobiety/ (accessed on 2 February 2021).

Dumowska, Bogumiła. 1986. “Anegdota o istnieniu”—Wokół liryków Haliny Poświatowskiej. Pamiętnik Literacki 77: $139-57$.

Eliade, Mircea, and Peter Couliano. 1990. Dictionnaire des Religions. Paris: Plon.

Encyklopedia Języka Polskiego. 2021. Religia. Warszawa: Wydawnictwo Naukowe PWN, Available online: https://encyklopedia.pwn. $\mathrm{pl} /$ haslo/religia;3966983.html (accessed on 10 January 2021).

Głowiński, Michał. 1960. W tonacji franciszkańskiej. Twórczość 7: 98-100.

Gowin, Rafał. 2019. Jem mięso. Warszawa: Convivo.

Graves, Robert. 1955. Greek Myths. London: Penguin Books.

Grądziel-Wójcik, Joanna. 2017. Poetyki i literatury momentalne. Między materią a metafizyka, czyli o chwycie paronomazji w poezji kobiet. Poznańskie Studia Polonistyczne 30. [CrossRef]

Grochowiak, Stanisław. 1959. Ciało. Wspótczesność 5: 8-9.

Grochowiak, Stanisław. 1967. Krzywda. Kultura 44: 3.

Hanusiewicz, Mirosława. 1998. Święte i zmysłowe w poezji religijnej polskiego baroku. Lublin: Wydawnictwo KUL.

Hernas, Czesław, and Mirosława Hanusiewicz, eds. 1995. Religijność literatury polskiego baroku. Seria Tradycje Literatury Polskiej. Lublin: Wydawnictwo KUL.

Hesiod VIII BC. 2021. Works and Days. Available online: https://chs.harvard.edu/primary-source/hesiod-works-and-days-sb/ (accessed on 19 January 2021).

Heydel, Magdalena. 2013. “Jeszcze żadna kobieta, jak poezja poezją...” Ku projektowi poetyckiemu Anny Świrszczyńskiej. In Różne głosy: Prace Ofiarowane Stanistawowi Balbusowi na jubileusz siedemdziesięciolecia. Edited by Dorota Wojda, Magdalena Heydel and Andrzej Hejmej. Kraków: Wydawnictwo Uniwersytetu Jagiellońskiego.

Iłłakowiczówna, Kazimiera. 1926. Połów. Warszawa: Wydawnictwo J. Mortkowicz.

Iłłakowiczówna, Kazimiera. 1927. Płaczacy ptak. Warszawa: Wydawnictwo F. Hoesic.

Iłłakowiczówna, Kazimiera. 1928. Z Głębi serca. Warszawa: Wydawnictwo Gebether i Wolf.

Iłłakowiczówna, Kazimiera. 1930. Popiót i perty. Warszawa: Wydawnictwo F. Hoesic.

Iłłakowiczówna, Kazimiera. 1967. Ta jedna nić. Wiersze religijne. Poznań: Wydawnictwo Św. Wojciecha.

Jakubowska-Fijałkowska, Genowefa. 1994. Dożywocie. Kraków: Miniatura.

Jakubowska-Fijałkowska, Genowefa. 2016a. ten diabeł ciąge mąci. In Eadem, Paraliż przysenny. Mikołów: Instytut Mikołowski. Jakubowska-Fijałkowska, Genowefa. 2016b. Bóg powrócił do miasta. In Eadem, Paraliż przysenny. Mikołów: Instytut Mikołowski.

Jakubowska-Fijałkowska, Genowefa. 2016c. Mężczyzna i Bóg. In Eadem, Paraliż przysenny. Mikołów: Instytut Mikołowski.

Jakubowska-Fijałkowska, Genowefa. 2016d. Ucho Van Gogha. In Eadem, Paraliż przysenny. Mikołów: Instytut Mikołowski.

Jakubowska-Fijałkowska, Genowefa. 2016e. Osiedlowy spleen. In Eadem, Paraliż przysenny. Mikołów: Instytut Mikołowski.

Jakubowska-Fijałkowska, Genowefa. 2016f. W sobotę koło dziewiątej rano. In Eadem, Paraliż przysenny. Mikołów: Instytut Mikołowski.

Jakubowska-Fijałkowska, Genowefa. 2016g. Ruletka z tobą. In Eadem, Paraliż przysenny. Mikołów: Instytut Mikołowski.

Jakubowska-Fijałkowska, Genowefa. 2016h. Niedziela. In Eadem, Paraliż przysenny. Mikołów: Instytut Mikołowski.

Jakubowska-Fijałkowska, Genowefa. 2016i. Rodzą się dziewczynki. In Eadem, Paraliż przysenny. Mikołów: Instytut Mikołowski.

Jakubowska-Fijałkowska, Genowefa. 2020a. Rośliny mięsożerne. Mikołów: Instytut Mikołowski. 
Jakubowska-Fijałkowska, Genowefa. 2020b. Wielkanoc 2018. In Eadem, Rośliny mięsożerne. Mikołów: Instytut Mikołowski. Jakubowska-Fijałkowska, Genowefa. 2020c. Święcona woda. In Eadem, Rośliny mięsożerne. Mikołów: Instytut Mikołowski.

Jakubowska-Fijałkowska, Genowefa. 2020d. Trzech Króli szóstego stycznia 2018. In Eadem, Rośliny mięsożerne. Mikołów: Instytut Mikołowski.

Jakubowska-Fijałkowska, Genowefa. 2020e. Boże Narodzenie 1986 (wspomnienie). In Eadem, Rośliny mięsożerne. Mikołów: Instytut Mikołowski.

Jakubowska-Fijałkowska, Genowefa. 2020f. Wielkanoc 2017. In Eadem, Rośliny mięsożerne. Mikołów: Instytut Mikołowski.

Jakubowska-Fijałkowska, Genowefa. 2020g. Jezus żonaty. In Eadem, Rośliny mięsożerne. Mikołów: Instytut Mikołowski.

Jakubowska-Fijałkowska, Genowefa. 2020h. Wszystko zawsze na matce wisi. In Eadem, Rośliny mięsożerne. Mikołów: Instytut Mikołowski.

Jamrożek, Wiesław, and Dorota Żołądż, eds. 1998. Rola i miejsce kobiet w edukacji i kulturze polskiej. Poznań: Instytut Historii Uniwersytetu Adama Mickiewicza, vol. 1.

Janion, Maria. 2006. Kobiety i duch inności. Warszawa: Sic!

Jay, Eldon Epp. 2005. Junia. The First Woman Apostle. Minneapolis: Fortress Press.

Judkowiak, Barbara. 1992. Słowo Inscenizowane. O Franciszce Urszuli Radziwiłłowej-Poetce. Poznań: Wydawnictwo WiS.

Kamieńska, Anna. 1981a. Przebudzenie. In Eadem, Wiersze jednej nocy. Warszawa: Ludowa Spółdzielnia Wydawnicza.

Kamieńska, Anna. 1981b. Stabat Mater. In Eadem, Wiersze jednej nocy. Warszawa: Ludowa Spółdzielnia Wydawnicza.

Karpiński, Adam. 2004. The Bogurodzica. In Ten Centuries of Polish Literature. Translated from Polish by Daniel Sax. Warszawa: Stowarzyszenie "Pro Cultura Litteraria"\& Fundacja Akademia Humanistyczna \& Instytut Badań Literackich PAN.

Kochanowski, Jan. 1986. Treny, Red. Janusz Pelc. Ser. BN I. Wrocław: Ossolineum. First published in 1580.

Koronkiewicz, Marta. 2014. Bargielska bez wymówek. Ślaskie Studia Polonistyczne 5: 212.

Krzyżanowski, Julian. 1978. History of Polish Literature. Tansleted by Doris Ronowicz. Warsaw: PWB-Polish Scientific Publishers.

Levallois, Anne, and Dominique Iogna-Prat. 2019. Religion (approche: Historico-philologique). In Dictionnaire des faits religieux. Dir. Régine Azriz, Danièle Hervieu-Léger, Dominique Iogna-Prat. Paris: PUF.

Malinowski, Wiesław Mateusz, and Jerzy Styczyński. 2008. La Pologne et les Polonais dans la littérature française. Siècles XIV-XIX. Paris: L'Harmattan.

Maliszewski, Karol. 2020. Bez zaszeregowania. O nowej poezji kobiet. Kraków: Universitas.

Marzec, Lucyna. 2018. Kazimiera Iłłakowiczówna mniej więcej znana. Poznańskie Studia Polonistyczne Seria Literacka 32: 75-94. [CrossRef]

Michałowska, Teresa. 2000. Modlitewnik Gertrudy. In Eadem, Średniowiecze. Warszawa: Wydawnictwo Naukowe PWN.

Mickiewicz, Adam. 1832. Dziady part III. In Idem, Poezye. Paryż: A. Pinard.

Mickiewicz, Adam. 1993. Do matki Polki. In Idem, Dzieła. Wiersze, Red. Czesław Zgorzelski. Edited by Zbigniew Jerzy Nowak, Zofia Stefanowska and Czesław Zgorzelski. Warszawa: Spółdzielnia Wydawnicza "Czytelnik", vol. I. First published in 1830.

Milewska-Waźbińska, Barbara. 2018. The Literary Heritage of Jesuits of the Polish-Lithuanian Commonwealth. Journal of Jesuit Studies Brill 5: 421-40. [CrossRef]

Nawarecki, Aleksander. 2013. «Co mam nie wierzyć». Justyna Bargielska i polskie zawstydzenie wiarą. In Więzi Wspólnoty. LiteraturaReligia-Komparatystyka. Edited by Piotr Bogalecki, Alina Mitek-Dziemba and Tadeusz Sławek. Katowice: Uniwersytet Śląski.

Osiecka, Agnieszka. 2009. Polska Madonna. In Wiersze prawie wszystkie. Warszawa: Wydawnictwo Prószyński i S-ka, vol. 1. First published in 1990.

Partyka, Joanna. 2004. "Żona wyćwiczona": kobieta piszaca w kulturze XVI i XVII wieku. Warszawa: Instytut Badań Literackich PAN.

Pawlikowska-Jasnorzewska, Maria. 1997. O biskupie fiołkowym. In Eadem, Poezje zebrane, Red. Aleksander Madyda, Preface: Krzysztof Ćwikliński. Torun: Algo, vol. 1. First published in 1922.

Pawlikowska-Jasnorzewska, Maria. 1997. Róże dla Safony. In Eadem, Poezje zebrane, Red. Aleksander Madyda, Preface: Krzysztof Ćwikliński. Toruń: Algo, vol. 1. First published in 1937.

Pawlikowska-Jasnorzewska, Maria. 1978. Roses for Sappho (Róże Dla Safony). History of Polish Literature. Translated by Doris Ronowicz. Warsaw: PWB-Polish Scientific Publishers. First published in 1937.

Perictyone 430 BC. 2021. (On Pythagoras). On the Duties of a Woman \& On a Harmony of a Woman. In The Complete Pythagoras. Edited by Roussel Patrick. Available online: http://holybooks.lichtenbergpress.netdna-cdn.com/wp-content/uploads/The-CompletePythagoras.pdf?30f3d7 (accessed on 9 January 2021).

Pernoud, Régine. 1998. Visages de femmes au Moyen Âge. L'Abbaye Sainte-Marie de la Pierre-qui-Vire (Yonne): Éditions Zodiaque.

Pollakówna, Joanna. 2012a. Kanikuła. In Eadem, Wiersze zebrane. Edited by Jan Zieliński. Mikołów: Instytut Mikołowski. First published in 1979.

Pollakówna, Joanna. 2012b. Szumy. In Eadem, Wiersze zebrane. Edited by Jan Zieliński. Mikołów: Instytut Mikołowski. First published in 1979.

Pope Paul VI. 1965. 17. The Religious Habits. Decree on the Adaptatio, and Renewal of Religious Life Perfectae Ca-ritatis. Available online: https://www.vatican.va/archive/hist_councils/ii_vatican_council/documents/vat-ii_decree_19651028_perfectae-caritatis_ en.html (accessed on 20 July 2021).

Poświatowska, Halina. 1958. Hymn batwochwalczy. Kraków: Wydawnictwo Literackie. 
Poświatowska, Halina. 2000. Inc. Boże zmiłuj się nade mną ... . In Eadem, Wszystkie wiersze. Red. Maria Smolarczyk. Kraków: Wydawnictwo Literackie. First published in 1966.

Prześluga, Malina, and Chór Czarownic. 2012a. Magnificat. Project of Ewa Łowżył. Translated by Thimothy Williams. Available online: https:/ / www.youtube.com/watch?v=lipdSIh1p_8\&t=7s (accessed on 3 March 2021).

Prześluga, Malina, and Chór Czarownic. 2012b. Oto słowo pańskie (Poland—This Is the Word of the Lord). Project of Ewa Łowżył. Translated by Thimothy Williams. Available online: https:/ / www.youtube.com/watch?v=lipdSIh1p_8 (accessed on 19 January 2021).

Prześluga, Malina. 2017. Twoja władza (Your Gouvernement). Performed by Chór Czarownic. Project of Ewa Łowżył. Translated by Thimothy Williams. First published 2016. Available online: https://www.youtube.com/watch?v=ls5u3uiawRA (accessed on 21 March 2021).

Prześluga, Malina, and Chór Czarownic. 2021. Kaciki ust (The Corners of the Mouths). Project of Ewa Łowżył. Translated by Thimothy Williams. Available online: https:/ / www.youtube.com/watch?v=sUOJFf315Dw (accessed on 26 February 2021).

Radzik, Zuzanna. 2018. Emancypantki. O kobietach, które zbudowaty Kościót. Warszawa: Wydawnictwo WAM.

Radzik, Zuzanna. 2020. Kościót kobiet. Warszawa: Wydawnictwo WAM.

Ratajczak, Józef. 1998. Kazimiera Iłłakowiczówna-Homo religiosus. Przegląd Powszechny 2: 164-72.

Ripa, Cesare. 2013. Religia. In Idem, Ikonologia. Translated by Ireneusz Kania. Kraków: Universitas. First published in 1593.

Rubik, Anja. 2018. \#SEXEDPL. Rozmowy Anji Rubik o dojrzewaniu, miłości i sexie. Warszawa: Wydawnictwo W.A.B.

Sadowska, Maria, dir. 2016. Sztuka kochania. Historia Michaliny Wisłockiej. Warsaw: Watchout Productions.

Słowacki, Juliusz. 1834. Kordian. Paryż: A. Pinard.

Stendahl, Krister. 1974. The Bible and the Role of Women. London: Facet Books.

Szot, Wojciech. 2017. Wojeciech Szot. Genowefa Jakubowska-Fijałkowska "Paraliż przysenny". April 19. Available online: https: / / zdaniemszota.pl/893-genowefa-jakubowska-fijalkowska-paraliz-przysenny (accessed on 22 February 2021).

Szymborska, Wisława. 1996. Głos w sprawie pornografii. In Eadem, Ludzie na moście. In Edeam Widok z ziarenkiem piasku. 102 wiersze. Poznań: Wydawnictwo a5. First published in 1986.

Tomasik, Wojciech. 2009. Pour la défense de «Tarcza» de Wisława Szymborska. Translated by Jeremy Lambert. Slavica Bruxellensia 2: 7-25. [CrossRef]

von Goethe, Johann Wolfgang. 1982. A. Faust I. In Idem, Sämtliche Werke. München: Hanser. First published in 1802.

von Stuckrad, Kocku. 2007. The Brill Dictionary of Religion. Amsterdam: Brill, vols. 1-4.

Weintraub, Wiktor. 1971. Tolerance and Intolerance in Old Poland. Canadian Slavonic Papers/Revue Canadienne Des Slavistes 13: 21-44. Available online: http:/ / www.jstor.org/stable/40866318 (accessed on 14 July 2021).

Wisłocka, Michalina. 2016. Sztuka Kochania. Warszawa: Agora. First published in 1978.

Ziętarski, Krzysztof. 2020. In Kasia Czyżewska, "Marka dla katoliczek: Co powinno być ukryte". Vogue. Available online: https: //www.vogue.pl/a/marka-dla-katoliczek-co-powinno-byc-ukryte (accessed on 23 April 2021). 